
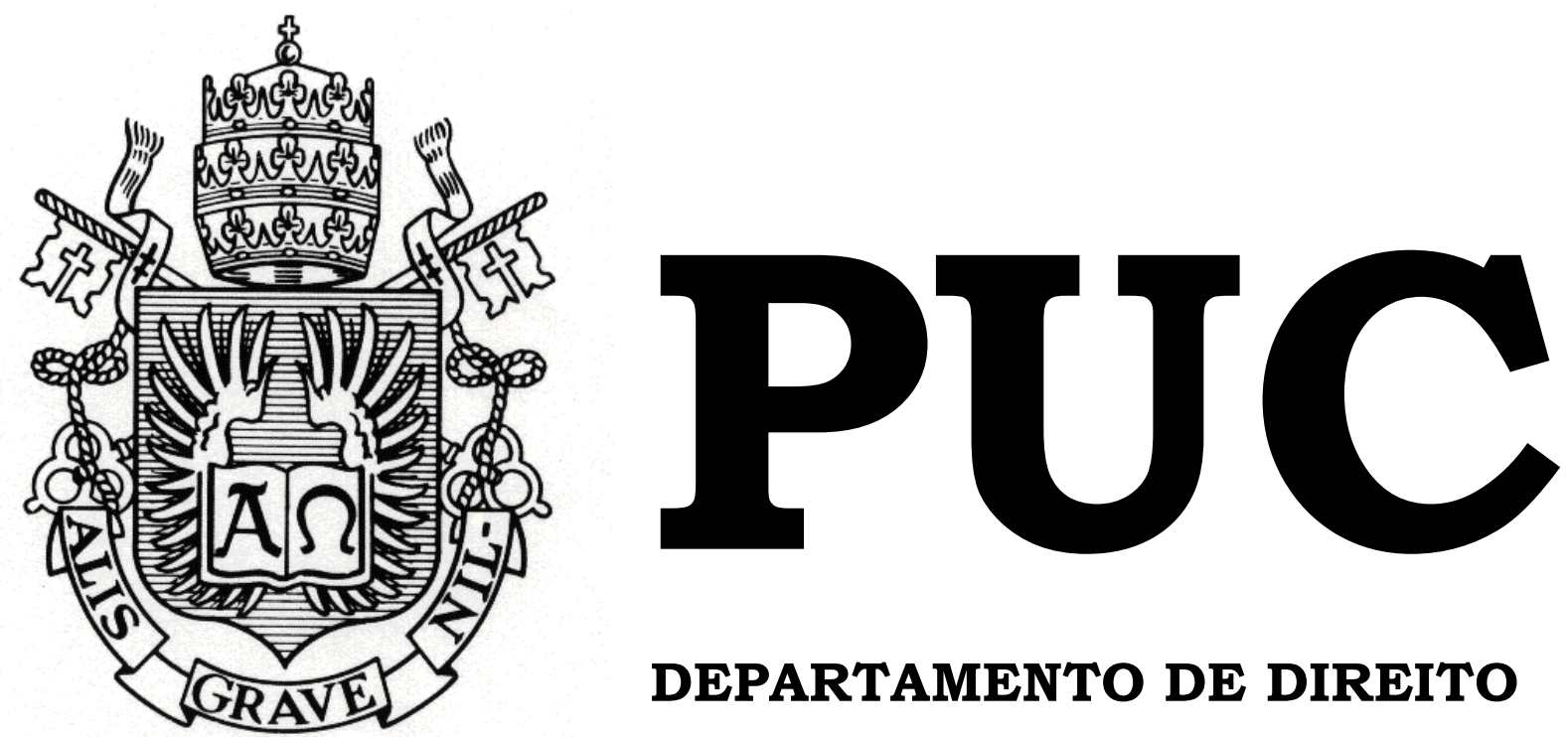

DEPARTAMENTO DE DIREITO

Oferta Pública de Aquisição de Ações de Companhia Brasileira por alienação do poder de controle acionário envolvendo Companhia estrangeira - Análise do caso Tim Participações S.A.

por

Fernanda Pereira da Rosa

ORIENTADOR(A): Pablo Waldemar Renteria 2010.2

PONTIFÍCIA UNIVERSIDADE CATÓLICA DO RIO DE JANEIRO

RUA MARQUÊS DE SÃO VICENTE, 225 - CEP 22451-900

RIO DE JANEIRO - BRASIL 


\section{Oferta Pública de Aquisição de Ações de Companhia Brasileira por alienação do poder de controle acionário envolvendo Companhia estrangeira - Análise do caso Tim Participações S.A.}

por

FERNANDA PEREIRA DA ROSA

Monografia apresentada ao Departamento de Direito da Pontifícia Universidade Católica do Rio de Janeiro (PUC-Rio) para a obtenção do Título de Bacharel em Direito.

Orientador(a): Pablo Waldemar Renteria 
Dedico o presente trabalho a todos aqueles que lutam pelo fiel cumprimento da lei e pelos ideais de igualdade preceituados na nossa Carta Maior, à propriedade, à livre iniciativa, à liberdade e principalmente à justiça. 


\section{AGRADECIMENTOS}

Agradeço a Deus por ser meu guia e minha luz.

Obrigada à minha mãe Carmelita Oliveira da Rosa por cumprir papel tão importante na consolidação dos meus valores morais e pela força exemplar tão inspiradora; ao meu namorado Guilherme Tortelote por todo o incentivo durante toda a minha graduação assim como pelo otimismo que me inspira a cada dia; aos professores Pablo Waldemar Renteria e Daniela Vargas pela coordenação e dedicação ao Programa de Treinamento em Mercado de Capitais no âmbito da Comissão de Valores Mobiliários; aos respeitados mestres Flavia Mouta Fernandes e Ricardo Maia da Silva, pelos ensinamentos sobre Mercado de Capitais. 


\section{RESUMO}

As negociações no mercado de capitais constituem fenômeno global marcado por um número significativo de operações societárias que resultam na alienação do controle acionário das companhias abertas.

Neste contexto, o presente trabalho analisa a oferta pública de aquisição de ações, designada pela sigla "OPA", como instrumento de proteção dos acionistas minoritários quando da mudança do poder diretivo da sociedade. Para isso, torna-se fundamental apontar os objetivos buscados pela norma ao denotar a obrigatoriedade de sua realização assim como conceituar as modalidades de controle acionário existentes no nosso ordenamento jurídico. Cumpre ressaltar, entretanto, que não é objetivo da presente monografia exaurir os aspectos procedimentais correlatos ao tema, dada a sua complexidade, mas sim esclarecer os fundamentos da obrigação prevista atualmente no art. 254-A da Lei ${ }^{\circ}$ 6.404/76.

Ao final, com o intuito de demonstrar a eficácia quanto ao cumprimento da ratio legis consubstanciada no referido dispositivo, apresentam-se os principais argumentos utilizados no julgamento de caso submetido ao Colegiado da Comissão de Valores Mobiliários ${ }^{1}$ quanto à alegada alienação de controle acionário envolvendo sociedade estrangeira e a companhia brasileira ${ }^{2}$ TIM Participações S.A.

\footnotetext{
${ }^{1}$ Comissão de Valores Mobiliários - CVM, autarquia federal com papel fiscalizador e regulamentador do mercado de capitais no Brasil, com poderes conferidos pela Lei $\mathrm{n}^{\circ} 6.385$, de 07.12.1976 e pela Lei $\mathrm{n}^{\circ}$ 6.404/76, para normatizar direitos e obrigações das companhias sob sua competência.

${ }^{2}$ Segundo Lamy Filho e Bulhões Pedreira é brasileira a sociedade organizada de conformidade com a lei brasileira e que tenha no país a sede de sua administração, nos termos do art. 1126 CC. A Lei $n^{\circ}$ 6.404/76 estabelece ainda em seu art. 269 que a sociedade de comando além de ser brasileira, tenha comando brasileiro.
} 


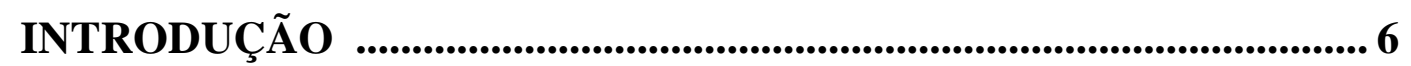

CAPÍTULO 1 - OFERTA PÚBLICA DE AQUISIÇÃO DE AÇÕES

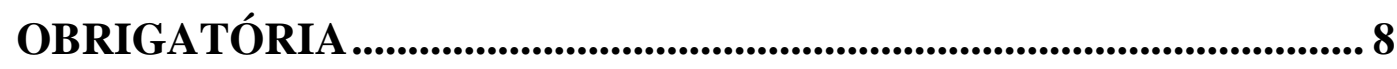

1.1 - Fundamento Legal e Normativo da OPA por Alienação do Controle

Acionário 12

1.2 - Função do Registro da OPA na Comissão de Valores Mobiliários (CVM) 22

CAPÍTULO 2 - PODER DE CONTROLE ACIONÁRIO 29

2.1 - Modalidades do poder de controle acionário 33

2.2 - Alienação do controle acionário e a importância da obrigatoriedade de realização de OPA 40

2.3 - Requisitos para a exigibilidade de realização de OPA em caso de alienação de controle: entendimento da Comissão de Valores Mobiliários (CVM)

\section{CAPÍTULO 3 - ANÁLISE DO CASO - PROCESSO CVM No}

RJ2009/1956: OPA DE TIM PARTICIPAÇÕES S.A ............................56

3.1 - Lei aplicável para a definição de controle - brasileira ou italiana - e a aplicabilidade do art. 254-A da Lei 6.404/76 ao caso ............................ 66

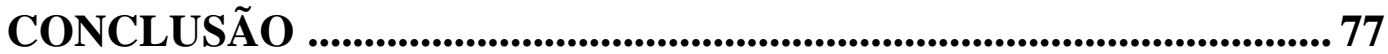

REFERÊNCIAS BIBLIOGRÁFICAS ..............................................79 


\title{
INTRODUÇÃO
}

\author{
"A tutela da minoria é um \\ problema econômico e político, \\ sendo jurídico somente o meio \\ através do qual essa tutela \\ atua". \\ Giuseppe Ferri ${ }^{3}$
}

O poder de controle acionário é tema amplo e abstrato que envolve não somente a mera detenção patrimonial de ações, mas está inserido em uma dimensão de direção dos negócios sociais, responsabilidade e lealdade para com os acionistas minoritários. Neste sentido, afirma José Edwaldo Tavares Borba ${ }^{4}$ que o controle é um fenômeno de poder, definindo que "controla uma sociedade quem detém o poder de comandá-la, escolhendo os seus administradores e definindo as linhas básicas de sua atuação". $\mathrm{Na}$ mesma linha de raciocínio, Modesto Carvalhosa ${ }^{5}$ discorre sobre a noção do poder de controle ao comentar a Lei $n^{\circ}$ 6.404, de 15 de dezembro de 1976 afirmando: "controle Societário pode ser entendido como o poder de dirigir as atividades sociais... Assim, o controle é o poder efetivo de direção dos negócios sociais"... "é controlador aquele que exerce, na realidade, o poder"

Dessa forma, o objeto da presente monografia é analisar a obrigatoriedade de realização de OPA em razão da modificação do poder de controle acionário da companhia. Por isso, é de fundamental importância apresentar os argumentos que fundamentam tal obrigatoriedade, apresentando os principais marcos históricos ligados à previsão legal da OPA decorrente da alienação do poder de controle acionário nas S.A.

\footnotetext{
${ }^{3}$ Apud BULGARELLI, Waldirio. Regime Jurídico da Proteção às Minorias nas S/A. (De acordo com a reforma da Lei $n^{\circ}$ 6.404/76). Rio de Janeiro: Renovar. 416p.

${ }^{4}$ BORBA, José Edwaldo Tavares. Direito Societário. $11^{a}$ Ed.Rio de Janeiro: Renovar, 2008. p. 346.

${ }^{5}$ CARVAlHOSA, Modesto. Comentários à Lei de Sociedades Anônimas. 2.ed. São Paulo:

Saraiva, 2003.p.429.
} 
É fundamental para o estudo da temática aqui apresentada percorrer brevemente sobre os conceitos do poder de controle acionário e a necessidade de proteção dos denominados acionistas "minoritários". A qualificação de tal tipo de acionista deve ser interpretada no sentido daqueles que se submetem a vontade da maioria e que carecem de proteção legal.

Em sequência, apresentam-se o conceito e os requisitos necessários para a alienação do poder de controle acionário, segundo entendimento doutrinário e da Comissão de Valores Mobiliários (autarquia federal responsável pela regulação, controle e fiscalização do mercado de capitais).

Por fim, apresentam-se os principais pontos dos votos proferidos ao caso TIM Participações S.A. que envolveu alegada alienação do poder de controle acionário desta companhia por parte de sua controladora indireta estrangeira. Verifica-se, portanto, se ocorre efetiva proteção aos acionistas minoritários por parte da Comissão de Valores Mobiliários ao analisar o conceito de controle e o direito aplicável em tal situação. 


\section{CAPÍtUlo 1 - OFERTA PÚblicA de AQUisiçÃo DE AÇÕES OBRIGATÓRIA}

A Oferta Pública de Aquisição de Ações ${ }^{6}$, designada pela sigla OPA, constitui uma declaração unilateral de vontade por meio da qual o proponente manifesta seu compromisso de adquirir um bloco de ações a um preço estipulado e segundo cláusulas e condiçõos previamente estabelecidas. ${ }^{7}$ Segundo Modesto Carvalhosa ${ }^{8}$, é uma proposta irrevogável dirigida a um número maior ou menor de acionistas indeterminados cujo objetivo é a realização de um negócio jurídico que possui como objeto a negociação de ações.

O objetivo da realização da oferta ${ }^{9}$ pública obrigatória é assegurar a todos os acionistas de determinada companhia aberta o direito de alienar as suas ações, em igualdade de condições, em decorrência de situações que alterem de forma significativa a composição acionária da companhia. ${ }^{10}$

Dessa forma, qualquer pessoa que tenha o intuito ou obrigação de adquirir quantidade substancial de ações emitidas por uma companhia aberta deve cumprir os requisitos estabelecidos na Instrução CVM n $361 / 2002$ que em seu art. $4^{\circ}, \S 4^{\circ}$ prevê que a OPA será dirigida indistintamente aos titulares de ações da mesma espécie e classe daquelas

\footnotetext{
${ }^{6}$ PRADO, Roberta Nioac. Oferta Pública de Ações Obrigatória nas S.A. - Tag Along. $1^{\circ}$ ed. São Paulo: Quartier Latin, 2005. p. 43.

${ }^{7}$ Tal conceituação encontra-se definida em EIZIRICK, Nelson; GAAL, Ariádna B.; PARENTE, Flávia; HENRIQUES, Marcus de Freitas. Mercado de Capitais Regime Jurídico. $2^{\mathrm{a}}$ Ed.Rio de Janeiro: Renovar,2008. p.551 e CARVALHOSA, Modesto. Oferta Pública de Aquisição de Ações.Rio de Janeiro: IBMEC, 1979. p.19.

${ }^{8}$ CARVAlHOSA, Modesto. Oferta Pública de Aquisição de Ações. Rio de Janeiro: IBMECInstituto Brasileiro de Mercado de Capitais, 1979.p.19.

${ }^{9}$ Com relação à natureza jurídica de tal oferta, dispõe o Código Civil brasileiro em seu art. 429 que prevê: "A oferta ao público equivale a proposta quando encerra os requisitos essenciais ao contrato, salvo se o contrário resultar das circunstâncias ou dos usos; § único: "Pode revogar-se a oferta pela mesma via de sua divulgação, desde que ressalvada esta faculdade na oferta realizada.

${ }^{10}$ EIZIRICK, Nelson; GAAL, Ariádna B.; PARENTE, Flávia; HENRIQUES, Marcus de Freitas. Mercado de Capitais Regime Jurídico. $2^{\mathrm{a}}$ Ed.Rio de Janeiro: Renovar,2008. p.551.
} 
que sejam objeto da OPA assim como deverá esta ser realizada de modo a garantir tratamento equitativo aos destinatários, permitindo-lhes a adequada informação quanto à companhia objeto e ao ofertante e a adoção por parte dos destinatários a respeito dos elementos necessários à tomada de uma decisão refletida e consciente quanto à aceitação da OPA.

A Lei 6.404/76 prevê as seguintes modalidades OPA: voluntária e obrigatória.

A forma voluntária decorre do interesse do ofertante em adquirir ações mediante apelo público aos vendedores ${ }^{11}$ e não em razão de uma norma que imponha obrigação em promovê-la, como ocorre na OPA obrigatória, tal tipo de oferta encontra-se prevista normativamente no art. $2^{\circ}$, inciso IV da Instrução CVM nº 361/2002 e não será regida pelos critérios estabelecidos nesta Instrução. Tal como dispõe o art. $2^{\circ}$, inciso $\mathrm{V}$ dessa Instrução, a OPA para aquisição de controle acionário, de que tratam os artigos 257 e seguintes da Lei das S.A., é modalidade de OPA voluntária. Incluem-se em tal modalidade a OPA voluntária propriamente dita, a concorrente que é aquela formulada por pessoa distinta do ofertante e que não seja a ele vinculada, e tem por objeto ações da OPA já em curso, como dispõe o art. $2^{\circ}$, inciso VI da Instrução CVM no $361 / 2002{ }^{12}$ assim como a OPA para aquisição do controle acionário regulamentada pelo art. 257 e seguintes da Lei das S.A. ${ }^{13}$

A OPA se torna obrigatória quando do (i) cancelamento de registro de companhia aberta, será formulada pelo acionista controlador ou pela própria companhia, tendo por objetivo a aquisição de todas as ações de emissão da companhia e como condição ao cancelamento do registro da companhia aberta, nos termos do art. $4^{\circ}, \S^{\circ}$ da Lei das S.A. e do art. $2^{\circ}$,

\footnotetext{
${ }^{11}$ Consoante orientação da Superintendência de Registro de Valores Mobiliários adotada no Processo CVM n ${ }^{\circ}$ RJ 2007/5587.

${ }^{12}$ EIZIRICK, Nelson; GAAL, Ariádna B.; PARENTE, Flávia; HENRIQUES, Marcus de Freitas. Mercado de Capitais Regime Jurídico. $2^{\mathrm{a}}$ Ed.Rio de Janeiro: Renovar,2008. p.552.

${ }^{13}$ PRADO, Roberta Nioac. Oferta Pública de Ações Obrigatória nas S.A. - Tag Along. $1^{\circ}$ ed. São Paulo: Quartier Latin, 2005. p. 43.
} 
inciso I da Instrução CVM no 361/2002; quando do (ii) aumento da participação do acionista controlador de companhia aberta a qual deve ser realizada em consequência de aumento da participação do acionista controlador no capital social, à porcentagem que, de acordo com as normas da CVM, impeça a liquidez de mercado das ações remanescentes, tendo por objetivo adquirir todas as ações de emissão da companhia, que sejam da classe ou espécie afetadas, nos termos do art. $4^{\circ}, \S 6^{\circ}$, da Lei de Sociedades por Ações e do art. $2^{\circ}$, inciso II da Instrução CVM n $361 / 2002$ e (iii) por alienação do controle acionário constituindo condição de eficácia ${ }^{14}$ de negócio jurídico de alienação, direta ou indireta, de controle de companhia aberta, sendo formulada pelo adquirente do controle e tendo por objetivo todas as ações de emissão da companhia com pleno e permanente direito de voto, nos termos do art. 254-A da Lei de Sociedades por Ações e do art. $2^{\circ}$, inciso III da Instrução CVM n ${ }^{\circ}$ 361/2002.

De acordo com a diferenciação apresentada, é válido aqui transcrever as palavras de Flavia Mouta ${ }^{15}$ ao explicar a diferenciação das modalidades de OPA existentes na legislação societária brasileira assim como os critérios adotados pela CVM para aferir a limitação de liquidez quando do aumento de participação acionária:

"Para que la compañia deje cotizar sus valores em Bolsa, su accionista
controlador debe formular uma oferta pública de adquisición de acciones para
accionistas minoritários, por precio justo, mediante la evaluación de la compañia
realizada por uma empresa de valoración, Independiente, aplicando los critérios
siguientes, adoptados de forma aislada o cumulativa: patrimônio líquido contable;

\footnotetext{
${ }^{14}$ A respeito de tal eficácia, é válido expor as palavras de Francesco Carnelutti em Teoria geral do direito.São Paulo:Lejus.1999.p.479: "Quando todos os requisitos previstos direta e indiretamente pela norma se reúnam no ato, produzir-se-ão os seus efeitos jurídicos, ou seja, à situação final a que temos a que temos chamado evento juntar-se-ão os efeitos jurídicos, o que tornará jurídica essa situação final e encerrará o ciclo do fato jurídico. A esta idoneidade de fato, por virtude de seus requisitos, para produzir os efeitos jurídicos, e, consequentemente, do evento para converter-se na situação jurídica final, chama-se eficácia de fato ou, em especial, eficácia do ato.” Em tal sentido dispõe o Código Civil em seu art. 125: "Subordinando-se a eficácia do negócio jurídico à condição suspensiva, enquanto esta se não verificar, não se terá adquirido o direito, a que ele visa"; em seu art. 127: "Se for resolutiva a condição, enquanto esta se não realizar, vigorará o negócio jurídico, podendo exercer-se desde a conclusão deste o direito por ele estabelecido".

${ }^{15}$ FERNANDES, Flavia Mouta. El caso de la OPA de Arcelor Brasil S.A. $24{ }^{\text {a }}$ ed. Madrid:

Revista Iberoamericana de Mercados de Valores, 2008, p. 13
} 
patrimônio líquido al precio de mercado; flujo de cajá descontado; múltiplos; o cotización de los valores em mercados públicos.

En cuanto a la OPA de perdida de liquidez, si El accionista controlador adquiere más de $1 / 3$ de las acciones de emisión de sua compañia controlada, limitando así la liquidez, deberá formular una OPA también por precio justo.

La OPA por toma de control tiene por finalidad que los accionistas de la sociedad opada puedan vender sus acciones a un precio, por lo menos, igual a $80 \%$ del valor que los accionistas controladores directos o indirectos recibieron por acción com derecho de voto. Es importante resaltar que esse tipo de OPA abarca solamente compañias con control concentrado y no aquellas con control pulverizado o disperso. Para esas compañias, en número creciente en Brazil, la OPA para toma de control es voluntária, y tiene por finalidad adquirir/comprar el control de uma compañia cotizada que no tiene un accionista controlador definido. No obstante, la característica de voluntariedad de este tipo de OPA para toma de control, requiere la autorización previa de la Comisión cuando la forma de pago conlleve permuta de valores". ${ }^{16}$

Ademais, pelo referido ensinamento, aduz-se a necessidade de registro na CVM, assunto que será apresentado em item a seguir, assim como a necessidade de definição do preço a ser pago aos destinatários da OPA por alienação de controle. Nesse sentido, é válido esclarecer que tal assunto será trabalhado no capítulo seguinte cujo objeto é o poder de controle acionário.

Quanto ao aspecto procedimental da OPA, a Instrução CVM n 361/2002 determina que esta será realizada mediante (i) Contratação de instituição financeira intermediária que atua como garantidora da OPA; b) Elaboração de laudo de avaliação da companhia objeto - apenas nas OPA formulada pela própria companhia, pelo controlador ou pessoa a ele vinculada; c) Registro na CVM -somente nas OPA obrigatórias e nas voluntárias que envolverem permuta por outros valores mobiliários; d) Publicação do instrumento da OPA, contendo todas as características da oferta, bem como informações sobre a companhia objeto e sobre o ofertante; e) Abertura de prazo para habilitação dos acionistas interessados; f) realização do leilão em bolsa de valores.

\footnotetext{
16 FERNANDES, Flavia Mouta. El caso de la OPA de Arcelor Brasil S.A. $24^{\text {a }}$ ed. Madrid: Revista Iberoamericana de Mercados de Valores, 2008, p. 13
} 


\section{1 - Fundamento Legal e Normativo da OPA por alienação de controle acionário}

Apresentadas as noções iniciais sobre a Oferta Pública de aquisição de Ações é importante aqui levantar os pontos relevantes que marcaram a evolução legal e normativa da OPA por alienação do controle acionário, atualmente regulamentada pelo art. 254-A da Lei das S.A. e pela Instrução $\mathrm{CVM} \mathrm{n}^{\circ} 361 / 2002^{17}$.

No direito comparado, a obrigatoriedade de realização de oferta pública (mandatory affers) quando da alienação de controle acionário foi inicialmente prevista com a promulgação do City Code inglês, em 1968. O fundamento de tal obrigatoriedade era permitir aos acionistas minoritários oportunidades igualitárias com relação aos controladores quando da alienação de controle acionário da companhia, ${ }^{18}$ como previu o direito francês e a $13^{\text {a }}$ Diretiva Européia. ${ }^{19}$

Até o advento da Lei 6.404/76, as sociedades por ações no Brasil eram reguladas pelo Decreto - lei 2.627, de 26.09.1940, que não dispunha de qualquer tipo de tratamento das cessões ou tomadas de controle de companhias abertas de forma a regular e/ou obrigar a realização de qualquer modalidade de OPA" 20

A partir da década de 50 houve uma grande difusão de operações de aquisição de controle de bancos comerciais seguida de sua incorporação, entretanto, a inexistência de regulamentação das cessões privadas de

\footnotetext{
${ }^{17}$ PRADO, Roberta Nioac. Oferta Pública de Ações Obrigatória nas S.A. - Tag Along. $1^{\circ}$ ed. São Paulo: Quartier Latin, 2005. p. 84

${ }^{18}$ EIZIRICK, Nelson; GAAL, Ariádna B.; PARENTE, Flávia; HENRIQUES, Marcus de Freitas. Mercado de Capitais Regime Jurídico. $2^{\mathrm{a}}$ Ed.Rio de Janeiro: Renovar,2008 p.584.

${ }^{19}$ Ibid.p.84.

${ }^{20}$ PRADO, Roberta Nioac. Oferta Pública de Ações Obrigatória nas S.A. - Tag Along. $1^{\circ}$ ed. São Paulo: Quartier Latin, 2005. p. 84
} 
controle permitia a obtenção de vantagens patrimoniais indevidas por parte dos controladores em consequência de vultosos ágios advindos de tais negociações societárias ${ }^{21}$.

As operações de compra e venda do controle envolviam o pagamento de valores levando-se em consideração os valores das cartas patentes dos bancos - autorizações do Governo para funcionamento de agências bancárias - confundindo então o valor do poder de controle, pertencente ao acionista controlador, com os intangíveis, pertencentes a toda a sociedade. Os valores pagos aos acionistas minoritários, quando da incorporação, eram calculados com base no patrimônio líquido contábil somente, desconsiderava o valor dos intangíveis. Em razão disso, os interesses patrimoniais dos acionistas minoritários eram prejudicados já que até aquele momento não possuíam resguardo legal..$^{22}$. Em razão disso, surgiu a idéia de assegurar aos minoritários o recebimento de parte da diferença entre o preço por ação do bloco de controle e o valor de mercado das ações, conforme o projeto de lei apresentado pelo Deputado Herbert Levy em 1972. ${ }^{23}$

Privilegiava a legislação em vigor à época os credores das companhias o que ocasionava reflexos negativos na ordem mercadológica omitindo-se o tratamento às cessões de controle que geravam danos ao mercado e aos investidores.

Um caso que ilustra o claro prejuízo dos acionistas minoritários na alienação de controle acionário se refere à operação societária de incorporação de instituição financeira da qual a Santa Casa de Misericórdia de São Paulo era acionista minoritária. Um grupo controlador do banco visava a incorporar a referida instituição financeira, em evidente situação de

\footnotetext{
${ }^{21}$ FILHO, Alfredo Lamy; PEDREIRA, José Luiz Bulhões. Direito das Companhias. $1^{\text {a }}$ ed. Rio de Janeiro: Editora Forense, 2009. p. 2004.

${ }^{22}$ Ibid. p. 2005.

${ }^{23}$ Ibid. p.2006.
} 
insider trading ${ }^{24}$, dirigiu-se à Santa Casa, e, em negociação direta e privada, fora do pregão, comprou suas ações por preço relativamente superior ao da cotação em Bolsa. Na semana seguinte, alienou à instituição financeira incorporadora o bloco de controle juntamente às demais ações adquiridas, por preço 12 vezes superior ao pago, preço esse previamente contratado e não divulgado, nem ao mercado nem à Santa Casa, causando assim patente prejuízo aos investidores que, ingenuamente, haviam alienado suas ações (no caso a Santa Casa de Misericórdia), em razão de desconhecerem os reais interesses que envolviam o negócio ${ }^{25}$.

A conduta maléfica considerada mais grave dos acionistas, controladores da instituição financeira, e que efetivamente causou danos à Santa Casa, foi o insider trading. Mas, tendo em vista que tal comportamento foi precedido por um prévio acordo de alienação de controle, que afinal ocorreu, a discussão girou em torno da regulação da alienação de controle de companhias abertas.

Assim, a necessidade de regulamentação dos direitos dos acionistas minoritários na alienação de controle acionário tinha por fundamento o questionamento quanto a apropriação dos intangíveis por parte do acionista controlador, não estendendo tal direito aos demais membros da sociedade; assim como pelo prêmio integral que era pago aos acionistas controladores

Dessa forma, em face de situações análogas àquelas, o legislativo identificou a necessidade de regulação da alienação de controle de instituição financeira companhia aberta; submeteu assim o Ministro da Fazenda ao Presidente da República exposição dos motivos na qual foram

\footnotetext{
24 "O insider trading consiste na utilização de informações relevantes sobre valores mobiliários, por parte de pessoas que, por força de sua atividade profissional, estão "por dentro" dos negócios da emissora, para transacionar com os valores mobiliários antes que tais informações sejam de conhecimento do público. Assim agindo, o insider compra ou vende valores mobiliários a preços que ainda não estão refletindo o impacto de determinadas informações, que são de seu conhecimento exclusivo" in EIZIRICK, Nelson; GAAL, Ariádna B.; PARENTE, Flávia; HENRIQUES, Marcus de Freitas. Mercado de Capitais Regime Jurídico.2 ${ }^{\mathrm{a}}$ Ed.Rio de Janeiro: Renovar,2008. p.552.

${ }^{25}$ Caso relatado em PRADO, Roberta Nioac. Oferta Pública de Ações Obrigatória nas S.A. - Tag Along. $1^{\circ}$ ed. São Paulo: Quartier Latin, 2005. p. 85.
} 
definidas as diretrizes básicas a serem observadas na elaboração do anteprojeto, inclusive a seguinte: "a lei estabelecerá mecanismos que impeçam que cada ação do majoritário possua valor potencial muito superior ao de cada minoritário; para tanto a lei deve prever um sistema de oferta pública para as transações que envolvam uma parcela substantiva da transferência do capital votante, de modo a assegurar a igualdade de acesso aos minoritários". ${ }^{26}$

O projeto de lei encomendado aos juristas Alfredo Lamy Filho e José Luiz Bulhões Pedreira, não contemplou o direito aqui levantado mas assegurou no Artigo 255 normas que:

“(a) subordinavam alienação de companhias aberta dependente de autorização governamental para funcionar à prévia aprovação da autoridade administrativa; (b) prescreviam a essa autoridade o dever de zelar para que fosse assegurado tratamento equitativo aos acionistas minoritários, mediante simultânea oferta pública para aquisição de suas ações, ou rateio, por todos os acionistas, dos intangíveis da companhia, inclusive autorização para funcionar; e (c) prescreviam que, no caso de compra de controle seguida de incorporação, esse tratamento equitativo devia ser apreciado no conjunto das operações". ${ }^{27}$

A criação do Artigo 255, entretanto, não logrou êxito, visto que o dispositivo protegia os acionistas minoritários de bancos comerciais contra operações de transferência de controle seguida de incorporação mas tal dispositivo não estendeu a todas as companhias abertas a participação dos minoritários no valor de alienação do controle pelos motivos que abaixo são citados por Alfredo Lamy e Luiz Bulhões:

"(a) toda a economia de mercado atribui valor econômico ao bloco de controle da companhia, que assegura ao seu titular o poder de determinar o destino da empresa, escolher seus administradores e definir suas políticas; (b) o valor do controle integra o patrimônio do controlador, e não da companhia; (c) os exemplos das vendas do controle de instituições financeiras, que apresentavam circunstâncias peculiares, não deviam servir de justificativa para normas gerais que pretendessem negar o valor de mercado do controle; e (d) o projeto seria contraditório se negasse o valor que o mercado atribui ao poder de controle distinto do valor das ações - ao mesmo tempo que propunha, inovando a legislação societária, a definição legal da responsabilidade do acionista controlador". ${ }^{28}$

\footnotetext{
${ }^{26}$ FILHO, Alfredo Lamy; PEDREIRA, José Luiz Bulhões. Direito das Companhias. $1^{\text {a }}$ ed. Rio de Janeiro: Editora Forense, 2009. p. 2006.

${ }^{27}$ Ibid. p. 2006.

${ }^{28}$ Ibid. p. 2006.
} 
Os trâmites de construção legislativa com o cunho de proteção dos acionistas minoritários demonstram um quadro conturbado e conflitante. O Projeto de Lei proposto por Herbert Levy em 1972 não contemplava mecanismos com intuito de proteção dos minoritários em caso de alienação de controle de companhia.

Os quadros societários demonstravam que, como ocorre atualmente, naquela época o controle exercido na maior parte das companhias nacionais, abertas e fechadas, amparavam-se em participação societária com direito de voto majoritária. Significa dizer: a quase totalidade das companhias brasileiras era controlada por detentores de ano menos 50\% mais uma ação votante". ${ }^{29}$

Entretanto, as duas propostas de emendas ao Artigo 255 do Projeto de Lei elaboradas pelos Deputados Alberto Hoffmann e Cunha Bueno e outra formulada pelo Deputado Herbert Levy não foram recepcionadas. Tais propostas tentaram introduzir ao Projeto o requisito da oferta pública com o intuito de garantir aos minoritários a oportunidade de vender suas ações ao mesmo preço unitário das ações de controle.

$\mathrm{O}$ argumento utilizado para tal recusa de proposta legislativa constava na Mensagem 204 por meio da qual o Presidente da República enviou ao Congresso Nacional a Exposição dos Motivos da Lei das S.A.. "Em seu item "d", a referida Mensagem declarava que, uma vez que os controladores possuíam responsabilidades próprias definidas na lei, das quais os minoritários não partilhavam, seria incoerente que não se atribuísse um valor econômico ao bloco acionário que garantisse o poder de controle da companhia, bem como seria da mesma forma incoerente estender aos minoritários esses benefícios econômicos". ${ }^{30}$

\footnotetext{
${ }^{29}$ PRADO, Roberta Nioac. Oferta Pública de Ações Obrigatória nas S.A. - Tag Along. $1^{\circ}$ ed. São Paulo: Quartier Latin, 2005. p. 88.

${ }^{30}$ Ibid.. p. 91.
} 
Dessa forma, o entendimento do Poder Executivo em tal momento era de que o prêmio de controle deveria ser exclusivamente e totalmente apropriado pelos acionistas controladores.

Porém, o Congresso Nacional adotou posição contrária a tal orientação na medida em que o Senado Federal e a Câmara dos Deputados aprovaram uma emenda apresentada pelo então Senador Lehmann ${ }^{31}$ que veio a constituir o Artigo 254 da lei das S.A. que além de garantir o tratamento igualitário aos acionistas minoritários mediante oferta pública de ações em casos de alienação de controle, atribuiu ainda competência ao Conselho Monetário Nacional (CMN) quanto à regulamentação da matéria.

Tal artigo foi editado no seguinte teor:

“A alienação do controle da companhia aberta dependerá de prévia autorização da Comissão de Valores Mobiliários.

$\S 1^{\circ}$ - A Comissão de Valores Mobiliários deve zelar para que seja assegurado tratamento igualitário aos acionistas minoritários, mediante simultânea oferta pública para aquisição de ações.

$\S 2^{\circ}$ - Se o número de ações ofertadas, incluindo as dos controladores ou majoritários, ultrapassar o máximo previsto na oferta, será obrigatório o rateio, na forma prevista no instrumento de oferta pública.

$\S 3^{\circ}$ - Compete ao Conselho Monetário Nacional estabelecer normas a serem observadas na oferta pública relativa à alienação do controle de companhia aberta". ${ }^{32}$

Nota-se que o tratamento dado pelo Artigo 254 e 255 da Lei das S.A. objetivou assegurar o tratamento igualitário a todos os acionistas detentores da mesma classe e espécie de ações emitidas por companhia aberta, quando da alienação de seu controle e se propôs a impedir que o acionista

\footnotetext{
31 "Otto Cyrillo Lehmann ficou conhecido pela emenda que levou seu nome e protagonizou o primeiro grande debate sobre o chamado "tag along" - até hoje motivo de controvérsias no mercado de capitais. Senador pela arena, Lehmann propôs à Comissão de Constituição e Justiça a alteração do art. 254 da Lei das S.A. e conseguiu condicionar a alienação de controle das companhias abertas à realização de oferta pública aos acionistas minoritários" in Direitos Iguais Revista Capital Aberto publicada em Julho de 2006 - página 30 - 31.

${ }^{32}$ FILHO, Alfredo Lamy; PEDREIRA, José Luiz Bulhões. Direito das Companhias. $1^{\text {a }}$ ed. Rio de Janeiro: Editora Forense, 2009. p. 2007.
} 
controlador se apropriasse do valor dos intangíveis de instituição financeira, respectivamente. Conferiu ao Conselho Monetário Nacional (CMN) a competência para a regulamentação da oferta pública relativa à alienação do controle acionário. Assim, o CMN baixou a Instrução 401 que, para fins de aplicação do art. 254 da Lei das S.A., definiu como acionistas minoritários todos aqueles que possuíssem ações com direito a voto.

Entretanto, a mudança do contexto político e econômico motivou a revogação dos Artigos 254 e 255 da Lei das S.A. sendo marcada a época pela implementação do Programa de Privatização das Companhias Estatais e Sociedades de Economia Mista por parte do então Presidente Fernando Henrique Cardoso. Afirma a doutrina que o Governo Federal foi a parte que auferiu vantagens diretas pela revogação dos dispositivos aqui mencionados.

Tal mudança no quadro político e econômico decorreu na revogação art. 254 da Lei 6.404/76 pelo artigo $6^{\circ}$ da Lei $\mathrm{n}^{\circ}$ 9.457/1997 (Projeto Kandir) com o intuito do Governo Federal em viabilizar o recebimento, pela União Federal, de todo o preço da alienação do controle de sociedades de economia mista privatizadas". 33

A revogação do Artigo 254 da Lei $n^{\circ} 6.404 / 76$ pelo Artigo $6^{\circ}$ da Lei $\mathrm{n}^{\circ}$ 9.457/1997 trouxe reflexos negativos à defesa dos acionistas minoritários, aos investidores e ao mercado de capitais como um todo na medida em que aquele artigo assegurava a regulação da alienação de controle de companhias abertas tornando obrigatória a extensão de condições e preços contratados pelo acionista controlador aos acionistas minoritários como levanta a ex-diretora da CVM Norma Parente ao referirse aos ágios pagos aos controladores que alienavam o seu poder de controle; estes eram exorbitantes e significavam uma injustiça já que não era dado ao acionista minoritário, titular de ações idênticas ao controlador,

\footnotetext{
${ }^{33}$ Ibid. p. 2007.
} 
direito de vender suas ações ao mesmo preço e junto com o controlador. Assim, a inexistência de norma legal obrigando a OPA a posteriori permitiu que os prêmios de controle fossem na ordem de $368 \%$ até $1.106 \%$, quando da alienação do controle acionário. ${ }^{34}$

Em tal conjuntura, a Comissão de Valores Mobiliários editou a Instrução CVM no 299/1999, que dispôs sobre a divulgação de informações na alienação de controle acionário e no aumento de participação de acionistas controladores, administradores e membros do conselho fiscal, adicionando regras relativamente à negociação de ações de própria emissão, e disciplina ofertas públicas para aquisição de ações.

Por meio de tal normatização, o controlador de uma companhia ficava limitado a adquirir novas ações de controle mediante realização de OPA a priori, por aumento de participação; de modo a assegurar o tratamento igualitário a todos os acionistas detentores da mesma espécie de ações, quando de sua alienação assim como normatizar as regras de disclosure. Assim dizia o Artigo 12 da referida Instrução:

\begin{abstract}
"A aquisição de ações de qualquer espécie e/ou classe, emitidas por companhias abertas, se dará, obrigatoriamente, através de oferta pública, quando o adquirente for acionista controlador cuja participação acionária, na oportunidade do negócio, já tenha se elevado, efetiva ou potencialmente, em dez por cento das ações da mesma espécie e/ou classe daquelas que constituam o objeto da aquisição, ou, ainda, promitente comprador, detentor de opção ou intermediário em negócio de transferência do controle acionário correspondente, bem como pessoa ligada a qualquer deles, de modo direto ou indireto, devendo ser observadas as seguintes regras básicas:
\end{abstract}

I - A oferta dirigida aos acionistas detentores de ações ordinárias ou preferenciais será submetida à prévia aprovação da CVM.

II - O prazo de validade da oferta não poderá ser inferior a quinze dias, sendo assegurada a livre interferência de terceiros.

III - O instrumento de oferta será publicado nos jornais utilizados habitualmente pela companhia.

IV - A oferta poderá ser condicionada à quantidade mínima de acionistas aceitantes.

\footnotetext{
${ }^{34}$ PARENTE, Norma. Principais inovações introduzidas pela Lei n. 10.303, de 31 de Outubro de 2001, à Lei de Sociedades por ações.In: Lobo, Jorge (Coord.).Reforma da Lei das Sociedades Anônimas.São Paulo: Forense, 2002.p.39
} 
V - Se a oferta for limitada a número máximo de ações, será assegurado o rateio proporcional entre os aceitantes, ressalvado o disposto no inciso VI.

VI - Verificada a habilitação de acionistas minoritários detentores, no seu conjunto, de quantidade superior a um terço das ações em circulação, o acionista controlador ou pessoa a ele vinculada sob qualquer forma deverá adotar a conduta por ele indicada no instrumento de oferta, nos termos do inciso VIII, alínea "e", desta instrução; (NR*)

VII - As ofertas públicas somente poderão ser formuladas com a intermediação de banco de investimento, sociedade corretora ou distribuidora de valores mobiliários, ou banco múltiplo com carteira de investimento, garantindo-se, em qualquer hipótese, o cumprimento das condições propostas pelo ofertante.(...)"

Apesar das inovações trazidas, as deficiências com relação ao modo como o acionista minoritário era tratado continuaram a existir até o advento da lei 10.303/2001, que realizou alterações na Lei $n^{\circ} 6.404 / 76$, a Lei das Sociedades por ações, dando uma nova redação ao Artigo $4^{\circ}$ e introduzindo o Artigo 254-A, o que importou em mudanças significativas do regime de Oferta Pública de Aquisição de Ações (OPA). A regulamentação por meio do referido artigo buscou (i) por um lado introduzir aspectos essenciais às ofertas lançadas por preço justo e (ii) por outro lado, reeditar as ofertas obrigatórias por alienação de controle acionário na regulação brasileira que haviam sido revogadas em 1997 pela Lei no 9.457.

As inovações trazidas pela Lei 10.303/2001 implicaram no retorno do direito de participação dos acionistas minoritários no preço de alienação de controle das companhias abertas, com a criação do artigo 254-A que trouxe modificações definindo que a

(a) "a alienação de controle" tem por objeto, além das ações integrantes do bloco de controle, ações vinculadas a acordos de acionistas, valores mobiliários conversíveis em ações com direito a voto, cessão dos direitos de subscrição de ações e outros títulos ou direitos relativos a valores mobiliários conversíveis em ações que venham a resultar na alienação de controle acionário da sociedade;

(b) a oferta do adquirente aos minoritários deve assegurar-lhes preço no mínimo igual a $80 \%$ do valor pago por ação com direito de voto integrante do bloco de controle; e

(c) o adquirente do controle acionário poderá oferecer aos acionistas minoritários a opção de permanecer na companhia mediante o pagamento de um prêmio 
equivalente à diferença entre o valor de mercado das ações e o valor pago por ação integrante do bloco de controle." ${ }^{35}$

Pela leitura do dispositivo aqui mencionado, verifica-se que neste não foi contemplado o princípio do tratamento igualitário, inicialmente previsto no art. 254 da Lei $n^{\circ} 6.404 / 76$, mas consagra a lei e a norma um valor econômico ao bloco de controle da companhia aberta já que as ações que compõem o bloco de controle recebem um preço superior ao dos acionistas minoritários quando da alienação do controle.

Assim, o art. 254-A da Lei $\mathrm{n}^{\circ}$ 6.404/76 determina que o adquirente do controle pague aos minoritários preço, no mínimo, igual a $80 \%$ do valor pago por ação integrante do bloco de controle, ${ }^{36}$ instituindo o mecanismo denominado tag along. ${ }^{37}$

O 254-A da Lei das S.A., nos termos do $\S 4^{\circ}$, possibilitou ainda que o adquirente do controle acionário ofereça aos acionistas minoritários a opção de permanecerem na companhia, mediante o pagamento de um prêmio, no mínimo equivalente à diferença entre o valor de mercado das ações e o valor pago por ação integrante do bloco de controle. ${ }^{38}$

A fim de regulamentar de forma normativa o referido artigo, a CVM, sob as atribuições conferidas pela Lei n_66.385 de 7 de dezembro de 1976 e pela Lei $n^{o} 6.404$ de 15 de dezembro de 1976, editou a Instrução CVM n

\footnotetext{
${ }^{35}$ FILHO, Alfredo Lamy; PEDREIRA, José Luiz Bulhões. Direito das Companhias. $1^{\text {a }}$ ed. Rio de Janeiro: Editora Forense, 2009. p. 2008.

${ }^{36}$ EIZIRICK, Nelson; GAAL, Ariádna B.; PARENTE, Flávia; HENRIQUES, Marcus de Freitas. Mercado de Capitais Regime Jurídico. $2^{\mathrm{a}}$ Ed.Rio de Janeiro: Renovar,2008. p.586.

${ }^{37} \mathrm{O}$ tag along é um mecanismo de proteção dos acionistas minoritários na hipótese de alienação do controle acionário da companhia. O referido mecanismo, previsto no art. 254-A da Lei das S.A. assegura que, na alienação de controle acionário de uma companhia, o adquirente deve se comprometer a realizar oferta pública de aquisição de ações ("OPA”) por, no mínimo, $80 \%$ do valor pago pelas ações integrantes do bloco de controle. Assim dispõe o artigo 254-A da Lei das S.A: "Art. 254-A. A alienação, direta ou indireta, do controle de companhia aberta somente poderá ser contratada sob a condição, suspensiva ou resolutiva, de que o adquirente se obrigue a fazer oferta pública de aquisição das ações com direito a voto de propriedade dos demais acionistas da companhia, de modo a lhes assegurar o preço no mínimo igual a $80 \%$ (oitenta por cento) do valor pago por ação com direito a voto, integrante do bloco de controle. (Incluído pela Lei $\mathrm{n}^{\circ} 10.303$, de 2001)

${ }^{38}$ EIZIRICK, Nelson; GAAL, Ariádna B.; PARENTE, Flávia; HENRIQUES, Marcus de Freitas. Mercado de Capitais Regime Jurídico. $2^{\mathrm{a}}$ Ed.Rio de Janeiro: Renovar,2008. p.589.
} 
361/2002 e determinou em seu art. $2^{\underline{o}}$, inciso III e no art. 29 a obrigatoriedade de realização de OPA obrigatória em caso de alienação de controle acionário assim como regulamentou todo o procedimento que deve ser obedecido na operacionalização de tal oferta pública.

\section{2 - Função do Registro da OPA na Comissão de Valores Mobiliários - CVM}

A lei das S.A. prevê duas modalidades de oferta pública de aquisição de ações, sendo a primeira para a tomada de controle acionário, prevista nos arts. 257 e 263, e a segunda modalidade por alienação do controle acionário, prevista no art. 254- A, sendo o prévio o registro na CVM obrigatório, ${ }^{39}$ por se tratar de troca de valores mobiliários.

Em se tratando de OPA por alienação do controle acionário, com fundamento no artigo 254-A da Lei 6.404/76, a Comissão de Valores Mobiliários (CVM) exercerá a função "fiscalizadora e registrária"40 , autorizada pela Lei $6.385 / 66$, coibindo abusos, fraudes e práticas não equitativas assim como assegurando a ampla publicidade dos atos aos acionistas minoritários e ao mercado de modo geral.

Valendo ser ressaltado que a análise por ela realizada envolverá um exame ao atendimento aos requisitos legais e regulamentares aplicáveis ao caso, não convindo a esta autarquia a manifestação quanto à "conveniência de demais aspectos subjetivos da alienação de controle em si”. ${ }^{41}$

\footnotetext{
${ }^{39}$ COMPARATO, Fábio Konder; FILHO, Calixto Salomão.O poder de Controle Acionário. $4^{\mathrm{a}}$ Ed. Rio de Janeiro: Forense,2005.p.258.

${ }^{40}$ BORBA, José Edwaldo Tavares. Direito Societário. 11 a Ed.Rio de Janeiro: Renovar, 2008. p. 171.

${ }^{41}$ PRADO, Roberta Nioac. Oferta Pública de Ações Obrigatória nas S.A. - Tag Along. $1^{\circ}$ ed. São Paulo: Quartier Latin, 2005. p. 251.
} 
$\mathrm{O}$ intuito da referida função fiscalizadora da CVM é averiguar o cumprimento aos pressupostos legais e regulamentares previstos na Lei 6404/76 e na Instrução CVM no 361/2002. Dessa forma, o contrato privado $^{42}$ de alienação de controle de companhia aberta deverá ser apresentado para que haja o seu exame e aprovação, juntamente com a minuta do Edital de Oferta Pública que deverá estender aos acionistas com direito de voto o pagamento de preço, no mínimo, igual a $80 \%$ do valor pago por ação com direito de voto integrante do bloco de controle ${ }^{43}$.

Havendo cumprimento aos pressupostos legais e normativos exigíveis ao contrato, a CVM dará provimento ao contrato de transferência onerosa das ações de controle da companhia aberta bem como da minuta do Edital de oferta pública de aquisição de ações de emissão da companhia e detidas pelos acionistas minoritários. ${ }^{44}$ Em tal sentido, afirma Roberta Nioac Prado:

“(...) a competência na análise pela CVM do contrato de transferência onerosa do poder de controle societário restringe-se a seus aspectos formais, uma vez que o princípio da autonomia privada, atualmente previsto nos arts. 421 e 422 do Código Civil, permite que, dentro dos limites da função social do contrato e observados os princípios de probidade e de boa-fé, os contratantes exerçam sua liberdade de contratar. $" 45$

Vale ser ressaltado que, nos termos da disposição do artigo 254-A da Lei ${ }^{\circ}$ 6.404/76, não há subordinação da alienação de controle à prévia autorização da CVM, mas declara que o negócio jurídico de alienação de controle somente pode ser contratado sob a condição, suspensiva ou resolutiva, de que o adquirente se obrigue a fazer a oferta pública de aquisição de ações, e o $\S 2^{\circ}$ dispõe que "a Comissão de Valores Mobiliários

\footnotetext{
${ }^{42}$ Em tal contrato deverá conter obrigatoriamente cláusula suspensiva ou resolutiva de realização de OPA para fins de eficácia do negócio jurídico de alienação do controle acionário.

${ }^{43}$ EIZIRICK, Nelson; GAAL, Ariádna B.; PARENTE, Flávia; HENRIQUES, Marcus de Freitas. Mercado de Capitais Regime Jurídico. $2^{\mathrm{a}}$ Ed.Rio de Janeiro: Renovar,2008. p.597.

${ }^{44}$ PRADO, Roberta Nioac. Oferta Pública de Ações Obrigatória nas S.A. - Tag Along. $1^{\circ}$ ed. São Paulo: Quartier Latin, 2005. p. 251.

${ }^{45}$ Ibid. p. 251
} 
autorizará a alienação de controle de que trata o caput, desde que verificado que as condições da oferta pública atendem aos requisitos legais. ${ }^{\$ 4}$

Será, portanto, considerada a condição como resolutiva quando a alienação do controle acionário tiver ocorrido antes da efetivação da oferta pública de aquisição de ações votantes dos minoritários. Será, entretanto, considerada suspensiva se os efeitos do contrato de alienação de controle não forem produzidos imediatamente, estando estes suspensos até a ocorrência da oferta pública. ${ }^{47}$

Nos termos do artigo 29, $\$ 6^{\circ}$ da Instrução CVM n 361/2002, há a obrigação por parte do ofertante em apresentar, em conjunto com o pedido de registro de OPA, a forma justificada quanto à forma de cálculo do preço devido aos acionistas minoritários, sobre a qual será analisada a ocorrência de eventuais práticas ilegais ou fraudulentas que visem reduzir o valor da OPA; inclusive "a competência e o dever legal para a CVM discutir o preço, estabelecido ou não por laudo de avaliação, estão fixados na lei, quando atribui ao órgão o dever de verificar se as condições da oferta atendem aos requisitos legais, nos termos do art. 245-A, caput e $\S 2^{\circ}$." ${ }^{48}$

Reitera-se que o deferimento do pedido de OPA não implica, por parte da CVM, garantia de veracidade das informações prestadas, julgamento sobre a qualidade da companhia objeto ou o preço ofertado pelas ações objeto da OPA, conforme dispõe o artigo $11, \S 1^{\circ}$ da Instrução.

Deverá ainda a alienação de controle ser comunicada ao mercado sob a forma de Fato Relevante, nos termos do $\$ 4^{\circ}$ do artigo 157 da Lei $n^{\circ}$ 6.404/76, por ser tal operação societária relevante na decisão dos investidores do mercado ao vender ou comprar valores mobiliários emitidos

\footnotetext{
${ }^{46}$ FILHO, Alfredo Lamy; PEDREIRA, José Luiz Bulhões. Direito das Companhias. $1^{\text {a }}$ ed. Rio de Janeiro: Editora Forense, 2009. p. 2004.

${ }^{47}$ EIZIRICK, Nelson; GAAL, Ariádna B.; PARENTE, Flávia; HENRIQUES, Marcus de Freitas. Mercado de Capitais Regime Jurídico. $2^{\mathrm{a}}$ Ed.Rio de Janeiro: Renovar,2008. p.599.

${ }^{48}$ SIQUEIRA, Carlos Augusto Junqueira de. Transferência do controle acionário: interpretação e valor. Rio de Janeiro: FMF Ed., 2004. p. 377.
} 
pela companhia. ${ }^{49}$ Tal obrigação é imposta normativamente por meio do artigo 10 da Instrução CVM no 358/2002, alterada pelas Instruções CVM nº 369/02 e 449/07.

A respeito da necessidade de publicação de comunicados ao mercado e quanto aos prazos para publicação das informações, dispõe Flavia Mouta Fernandes:

"La sociedad oferente tiene que divulgar, por medio de la publicación de um hecho relevante, la realización de la oferta pública de adquisición de acciones de uma sociedad cotizada.

Tras la publicación, los inversores ya saben que el oferente tiene treinta dias para hacer la solicitud de registro de la OPA em la Comisión, presentando los siguientes documentos: el contracto del oferente y de la institución financiera, que garantiza la liquidación financiera de la operación; el borrador del dolleti informativo llamado Edital; y el informe de valoración llamado Laudo.

La operación generalmente está autorizada em sesenta dias y el oferente tiene más 10 días para publicar el Edital. El plazo de aceptación es de treinta hasta cuarenta y cinco dias después de la publicación.

Finalmente, la Bolsa tiene que enviar el resultado de la oferta a la Comisión em cuatro dias hábiles." 50

Por fim, suscitados os requisitos de caráter procedimental ao registro de OPA por alienação de controle acionário perante a CVM, deve ficar claro que a realização de tal oferta não é limitada aquelas cujos registros são submetidos a esta Comissão, podendo esta autarquia determinar a realização de uma oferta pública obrigatória de aquisição de ações aos acionistas minoritários quando entender que houve de fato alienação de controle acionário, nos termos do artigo 254-A da Lei 6.404/76.

Em tal sentido, é válido transcrever o que dispõe o artigo 29 da Instrução CVM no 361/2002:

"Art. 29. A OPA por alienação de controle de companhia aberta será obrigatória, na forma do art. 254-A da Lei 6.404/76, sempre que houver alienação, de forma

\footnotetext{
${ }^{49}$ FILHO, Alfredo Lamy; PEDREIRA, José Luiz Bulhões. Direito das Companhias. $1^{\text {a }}$ ed. Rio de Janeiro: Editora Forense, 2009. p. 2004.

${ }^{50}$ FERNANDES, Flavia Mouta. El caso de la OPA de Arcelor Brasil S.A. 24 a ed. Madrid: Revista Iberoamericana de Mercados de Valores, 2008, p. 14.
} 
direta ou indireta, do controle de companhia aberta, e terá por objeto todas as ações de emissão da companhia às quais seja atribuído o pleno e permanente direito de voto, por disposição legal ou estatutária.

$\S 1^{\circ}$ A OPA deverá ser formulada pelo adquirente do controle, e seu instrumento conterá, além dos requisitos estabelecidos pelo art. 10, as informações contidas na notícia de fato relevante divulgada quando da alienação do controle, sem prejuízo do disposto no inciso I do $\S 1^{\underline{o}}$ do art. 33, se for o caso.

$\S 2^{-}$O requerimento de registro da OPA de que trata o caput deverá ser apresentado à CVM no prazo máximo de 30 (trinta) dias, a contar da celebração do instrumento definitivo de alienação das ações representativas do controle, quer a realização da OPA se constitua em condição suspensiva, quer em condição resolutiva da alienação.

$\S^{\circ}$ O registro da OPA pela CVM implica na autorização da alienação do controle, sob a condição de que a oferta pública venha a ser efetivada nos termos aprovados e prazos regulamentares.

\$4 $4^{0}$ Para os efeitos desta instrução, entende-se por alienação de controle a operação, ou o conjunto de operações, de alienação de valores mobiliários com direito a voto, ou neles conversíveis, ou de cessão onerosa de direitos de subscrição desses valores mobiliários, realizada pelo acionista controlador ou por pessoas integrantes do grupo de controle, pelas quais um terceiro, ou um conjunto de terceiros representando o mesmo interesse, adquira o poder de controle da companhia, como definido no art. 116 da Lei 6.404/76.

$\S 5^{\circ}$ Sem prejuízo da definição constante do parágrafo anterior, a CVM poderá impor a realização de OPA por alienação de controle sempre que verificar ter ocorrido a alienação onerosa do controle de companhia aberta. (grifado)

$\S 6^{\underline{0}}$ No caso de alienação indireta do controle acionário, o ofertante deverá submeter à CVM, juntamente com o pedido de registro, a demonstração justificada da forma de cálculo do preço devido por força do art. 254-A da Lei 6.404/76, correspondente à alienação do controle da companhia objeto."

Para melhor entendimento da matéria trazida à análise no referido no dispositivo, é fundamental o entendimento a respeito dos conceitos básicos sobre o poder de controle acionário e a alienação de controle acionário, temas que serão trabalhados no capitulo seguinte.

É importante aqui ressaltar que a imposição de realização de OPA, de forma fundamentada, nos termos do $\S 5^{\circ}$ supramencionado, é realizada na forma de decisões dos Superintendentes da CVM. Podendo tal manifestação ser questionado por meio de Recurso ao Colegiado, órgão 
máximo da CVM, mediante apresentação dos argumentos por parte das áreas técnicas desta Comissão e das partes interessadas.

Não é incomum a identificação de operações societárias das quais decorrem alienação indireta de controle acionário sobre as quais é dever da CVM intervir de forma a evitar o tratamento não equitativo aos acionistas minoritários. Tal como enfatiza Carlos Augusto Junqueira sobre a atuação da CVM nos procedimentos relativos à alienação de controle, de modo que esta autarquia visa não apenas verificar os requisitos formais do negócio e da posterior oferta pública de extensão, como, principalmente, realizar o exame do preço e das condições que serão estendidas na oferta para a compra das ações votantes existentes em circulação. Esclarece o autor que constitui seu dever legal da CVM assegurar aos acionistas não controladores o recebimento de proposta de compra por suas ações, nos termos determinados pela lei, podendo, para tanto, definir o preço e as condições da oferta. Não só por critérios apropriados mas, especialmente, com fundamento nas condições verificadas na transferência do controle, concluindo em linha com a realidade econômica da transação.

Para tanto, deve perquirir, em profundidade, as circunstâncias concretas de cada operação, para que a aplicação da lei não seja prejudicada por mantos formais que, muitas vezes, escondem a real extensão dos atos praticados com a finalidade de transferir o controle da companhia aberta.

Em face da complexidade apresentada em muitas operações da espécie, a CVM adotou, como premissa, proceder à análise casuística das transferências de controle acionário para melhor exercer seu dever de tutela, que visa a preservar os direitos dos acionistas minoritários."

Com base no acima exposto, se torna imprescindível o registro da OPA na CVM a fim de que esta autarquia exerça o seu papel regulamentar,

\footnotetext{
${ }^{51}$ SIQUEIRA, Carlos Augusto Junqueira de. Transferência do controle acionário: interpretação e valor. Rio de Janeiro: FMF Ed., 2004. p. 31.
} 
de controle, fiscalização e desenvolvimento do mercado de capitais. Garantindo assim a segurança jurídica e o cumprimento das regras de controle e proteção dos atos societários.

Insta salientar que além do controle feito à OPA sob a égide normativa, consoante à aplicação da legislação societária, há espaço para a interpretação das cláusulas contratuais com fundamento no Código Civil que em seus artigos 423 e 424 prevêem, respectivamente, a interpretação favorável ao aderente de cláusulas ambíguas e a nulidade de cláusulas de renúncia a direito, o que, segundo Fabio Comparato ${ }^{52}$ constituem um importante complemento à regulamentação publicística das ofertas, o que permite maior equilíbrio nas relações entre ofertante e acionistas.

${ }^{52}$ COMPARATO, Fábio Konder; FILHO, Calixto Salomão.O poder de Controle Acionário. $4^{\mathrm{a}}$ Ed. Rio de Janeiro: Forense,2005.p.259. 


\section{CAPÍTULO 2 - O PODER DE CONTROLE ACIONÁRIO}

A definição de poder de controle acionário é fundamental para o exame da obrigatoriedade de realização da OPA prevista no art. 254-A da Lei das S.A., dessa forma, aqui serão brevemente expostos os principais pontos para a compreensão da matéria tendo em vista que tal tema não constitui ponto principal do trabalho e o conhecimento do poder de controle $^{53}$ é um tema amplo cujo conteúdo antecede a sua própria definição legal.

É importante notar que a análise da expressão "controle de companhia" é expressa nas formas de "poder de controle" e "bloco de controle", comportando assim uma interpretação ambígua sobre o assunto ${ }^{54}$ já que o emprego do termo controle da companhia é usado tanto para representar o poder de fato - na determinação das atividades sociais (poder de controle) - quanto para referir-se ao conjunto de ações com direito a voto (bloco de controle) que é, na verdade, fonte do poder de controle. ${ }^{55}$

A análise a ser realizada no presente capítulo comportará o exame do "poder de controle acionário" segundo a Lei das S.A., em definições

\footnotetext{
${ }^{53}$ Segundo Fábio Konder Comparato em O poder de controle na sociedade por ações analisa a origem semântica do 'Controle' examinando a origem do vocábulo, "segundo os etimologistas, é francesa, mas a evolução semântica, no vernáculo, sofreu nítida influência do inglês, como ocorreu, aliás, até mesmo na língua de origem" (Comparato \& Salomão Filho, 2005, p.27). Para a língua francesa, controle vem do arcaico substantivo contrerôle, o que aduz um sentido básico de verificação ou fiscalização para o direito francês, o qual traz a expressão "contrôle des societés anonymes" (ibidem, p.28). De forma muito pertinente, Comparato contrapõe o sentido dado pela língua francesa à elaborada pela inglesa, para a qual "ao contrário, o núcleo central das diferentes acepções do vocábulo é a noção de poder ou de dominação". Considerando as oposições semânticas trazidas pelas línguas inglesa e francesa, percebe-se que o nosso português sofreu influência tanto de uma, como da outra. Assim sendo, nota-se que a palavra 'controle' assumiu uma dupla faceta,e, segundo Comparato, "passou a significar, correntemente, não só a vigilância, verificação, fiscalização, como ato ou poder de dominar, regular, guiar ou restringir"

${ }^{54}$ FILHO, Alfredo Lamy; PEDREIRA, José Luiz Bulhões. Direito das Companhias. $1^{\text {a }}$ ed. Rio de Janeiro: Editora Forense, 2009. p. 823.

${ }^{55}$ FILHO, Alfredo Lamy; PEDREIRA, José Luiz Bulhões. A Lei das S.A.Rio de Janeiro: Renovar,1992. p. 698.
} 
construídas em função da titularidade da maioria dos votos e com base no exercício do poder diretivo dos negócios sociais.

Inicialmente deve ficar claro que o poder de controlar comporta a capacidade de "governar, dirigir ou pilotar, o que explica a designação do poder exercido pelo acionista controlador" 56

Ademais, a expressão "controle de companhia" também comporta a o significado de conjunto de ações de propriedade do acionista controlador, referido como "bloco de controle", sendo o "bloco" interpretado com o significado de coisa coletiva e "de controle" por constituir fonte do poder de controle ${ }^{57}$.

O conceito geral a respeito do acionista controlador encontra-se previsto no caput do art. 116 da Lei das S.A. e é reiterado no inciso IV do art. $3^{\circ}$ da Instrução CVM no 361/2002, respectivamente das seguintes formas:

Art. 116: "Entende-se por acionista controlador a pessoa, natural ou jurídica, ou o grupo de pessoas vinculadas por acordo de voto, ou sob controle comum, que: a) é titular de direitos de sócio que lhe assegurem, de modo permanente, a maioria dos votos nas deliberações da assembléia-geral e o poder de eleger a maioria dos administradores da companhia; e b) usa efetivamente seu poder para dirigir as atividades sociais e orientar o funcionamento dos órgãos da companhia."

Art. 30: Para os efeitos desta Instrução, entende-se por: (...) Inciso IV: acionista controlador: a pessoa, natural ou jurídica, fundo ou universalidade de direitos ou o grupo de pessoas vinculadas por acordo de voto, ou sob controle comum, direto ou indireto, que: a) seja titular de direitos de sócio que lhe assegurem, de modo permanente, a maioria dos votos nas deliberações da assembléia geral e o poder de eleger a maioria dos administradores da companhia; e b) use efetivamente seu poder para dirigir as atividades sociais e orientar o funcionamento dos órgãos da companhia.

Pelas definições trazidas pela legislação societária o acionista controlador será definido, de maneira geral, por aquele titular de ações ordinárias - que lhe conferem direito a voto, que possui poder de dirigir a companhia ou eleger quem irá dirigi-la ${ }^{58}$, de forma efetiva. Dessa forma,

\footnotetext{
${ }^{56}$ Ibid. p. 827.

${ }^{57}$ Ibid.p.826.

${ }^{58}$ PRADO, Roberta Nioac. Oferta Pública de Ações Obrigatória nas S.A. - Tag Along. $1^{\circ}$ ed. São Paulo: Quartier Latin, 2005. p. 122..
} 
não será considerado acionista controlador aquele que possuir quantidade de ações que teoricamente the assegurem a maioria dos votos em assembléia geral, porém, não utiliza efetivamente tal poder para impor a sua vontade na condução da sociedade, seja nos negócios seja na eleição da maioria dos administradores.

No presente contexto, cumpre ressaltar a diferenciação realizada pela doutrina entre poder de controle interno e externo; o primeiro decorre da titularidade de ações votantes de emissão da companhia de forma que permita a seu titular o exercício do poder de direção previsto no art. 116 da Lei das S.A., ou seja, tal poder advém da estrutura interna da companhia e se funda no direito de voto atribuído pela titularidade de ações, por isso é também conhecido como poder de controle acionário. ${ }^{59}$ De forma distinta ao denominado controle externo, tal modalidade de poder é a que importa para a análise da obrigatoriedade da OPA prevista no art. 254- A da Lei das S.A. O titular do controle interno atua no interior da sociedade (ab intus),

com base em mecanismos de poder próprios da estrutura societária, notadamente a deliberação em assembléia. ${ }^{60}$

O controle externo é entendido como aquele que resulta do poder de influência à companhia decorrente de direitos de crédito contra a sociedade ou em relações nos mercados ${ }^{61}$ e limita-se a alguns negócios ou a algumas atividades, podendo ser exercido por qualquer pessoa jurídica ou natural que exerça a função empresarial. O exercício de tal influência é fundado de diversas maneiras, tais como a existência de endividamento da sociedade, o depósito à vista em instituições financeiras, a emissão de debêntures, a sociedade em conta de participação, a concessão de vendas com

\footnotetext{
${ }^{58}$ FILHO, Alfredo Lamy; PEDREIRA, José Luiz Bulhões. Direito das Companhias. $1^{\text {a }}$ ed. Rio de Janeiro: Editora Forense, 2009. p. 251

${ }^{59}$ Ibid. p. 830.

${ }^{60}$ COMPARATO, Fábio Konder; FILHO, Calixto Salomão.O poder de Controle Acionário.4 ${ }^{a}$ Ed. Rio de Janeiro: Forense,2005.p.48.

${ }^{61}$ FILHO, Alfredo Lamy; PEDREIRA, José Luiz Bulhões. Direito das Companhias. $1^{\mathrm{a}}$ ed. Rio de Janeiro: Editora Forense, 2009. p. 831.
} 
exclusividade e o franchising $^{62}$, desde que tais situações tenham o condão de influenciar no poder decisório e de administração da sociedade. É importante frisar que o exercício de tal modalidade de controle não importa para a análise de exigibilidade de incidência da OPA prevista no art. 254-A da Lei das S.A e do art. 29 da Instrução CVM no 361/2002. Por fim, tal poder pertence a uma ou mais pessoas que não compõem quaisquer órgãos da sociedade mas agem de fora ( $a b$ extra), não decorrendo do direito a voto conferido por ação ou acordo de acionistas. ${ }^{63}$

Insta salientar que o poder de controle constitui um poder de fato ${ }^{64} \mathrm{e}$ não jurídico. Segundo Lamy ${ }^{65}$, o poder de controle não é poder jurídico contido no complexo de direitos da ação, tal poder existe a partir da reunião na mesma pessoa ou grupo de pessoas da quantidade de ações cujos direitos de votos, quando exercidos no mesmo sentido, formando a maioria no poder decisório ${ }^{66}$ da companhia. Não é considerado, portanto, objeto de direito subjetivo com apreciação econômica.

Para a definição de acionista controlador a legislação societária brasileira adotou o Princípio majoritário que constitui a regra do regime de funcionamento dos órgãos que possuem deliberação conjunta na

\footnotetext{
62 Ibid.

${ }^{63}$ COMPARATO, Fábio Konder; FILHO, Calixto Salomão.O poder de Controle Acionário.4 ${ }^{\mathrm{a}}$ Ed. Rio de Janeiro: Forense,2005.p.48.

64 Em: FILHO, Alfredo Lamy; PEDREIRA, José Luiz Bulhões. Direito das Companhias. $1^{\mathrm{a}}$ ed. Rio de Janeiro: Editora Forense, 2009. p. 828: "Essa natureza do poder fica evidente quando se considera que (a) não há norma legal que confira ou assegure o poder controle: ele nasce do fato da formação do bloco de controle e deixa de existir com a sua dissolução, (b) o poder de controle não é objeto de direito: não pode ser adquirido, nem transferido independentemente do bloco de controle, que é a sua fonte e (c) o poder de controle não é direito subjetivo: o acionista controlador não pode pedir a tutela do Estado para obter que esse poder seja respeitado, a não ser quando se manifesta por meio do exercício regular do direito (ou poder jurídico) de voto nas deliberações da Assembléia Geral."

${ }^{65}$ FILHO, Alfredo Lamy; PEDREIRA, José Luiz Bulhões. Direito das Companhias. $1^{\text {a }}$ ed. Rio de Janeiro: Editora Forense, 2009. p.827.

$66 \mathrm{O}$ poder decisório aqui referido pode ser entendido como o poder de comando sobre as atividades desenvolvidas pela companhia, quando da eleição da maioria dos administradores assim como no direcionamento das ações da sociedade, exteriorizado na Assembléia Geral, no Conselho de administração ou nas denominadas "reuniões prévias" das quais participam os acionistas integrantes de acordos de acionistas de forma a manifestar a vontade social da companhia.
} 
companhia, sendo o poder decisório reflexo da maioria dos votos, desde que atendidos os requisitos legais e estatutários da sociedade por ações. ${ }^{67}$

\section{1 - MODALIDADES DO PODER DE CONTROLE ACIONÁRIO}

Apresentada a conceituação básica a respeito do controle acionário, nos termos da Lei no 6.404/76 e da Instrução CVM nº 361/2002 assim como a diferenciação doutrinária entre controle interno e externo, e entre o poder de fato e de direito, é válido apresentar uma exposição breve sobre as distintas modalidades pelas quais o poder de controle acionário é exercido. A análise aqui trazida possui a finalidade de melhor compreensão da obrigação prevista no art. 254- A da lei das S.A. que constitui ponto principal do presente trabalho.

Inicialmente cumpre esclarecer que o exame com relação à existência da obrigação de lançamento de OPA obrigatória, importa-nos conhecer a diferenciação existente entre os conceitos doutrinário de poder de controle majoritário e o poder de controle minoritário.

Sob a premissa de que controla uma sociedade quem possui o poder de comandá-la escolhendo os seus administradores e definindo as linhas básicas de sua atuação ${ }^{68}$, o controle majoritário é aquele que é exercido pelos acionistas que detêm a maioria absoluta do capital votante emitidos pela companhia, sendo no mínimo 50\% mais uma ação ordinária com direito a voto. Em tais companhias a detenção de ações que asseguram o poder de controle se sobrepõe às funções executivas, particularmente aquelas que são atribuídas ao conselho de administração ${ }^{69}$. Tal modalidade

\footnotetext{
${ }^{67}$ Ibid.p.808.

68 BORBA, José Edwaldo Tavares. Direito Societário. $11^{\mathrm{a}}$ Ed. Rio de Janeiro: Renovar.2008.p.346.

${ }^{69}$ EIZIRICK, Nelson; GAAL, Ariádna B.; PARENTE, Flávia; HENRIQUES, Marcus de Freitas. Mercado de Capitais Regime Jurídico.2 ${ }^{\mathrm{a}}$ Ed.Rio de Janeiro: Renovar,2008. p.278.
} 
de controle pode ser exercida de forma individual ou conjunta, unidos por acordo de votos escrito ou tácito, ou seja, os acionistas podem se vincular por meio de acordo de acionistas a ser arquivado na sede da companhia, nos termos do art. 118 da Lei das S.A., ou informalmente - sem que haja acordo escrito entre as partes. Tal modalidade de controle também é denominada doutrinariamente como controle de direito uma vez que o acionista exercerá o controle efetivo e permanente da sociedade "independentemente de outras variáveis necessárias para o exercício do poder de controle minoritário, tal como a dispersão acionária do controle de companhia aberta". $^{70}$

O entendimento do conceito de poder de controle majoritário importa à análise quanto à aplicabilidade do art. 254- A da Lei das S.A., na medida em que permite averiguar se houve a transferência da maioria absoluta das ações votantes da companhia, sendo no mínimo $50 \%$ mais uma ação com direito a $\operatorname{voto}^{71}$. Lembrando que tal operação que será analisada casuisticamente pela CVM nos termos das atribuições conferidas pela Lei $n^{\circ}$ 6.385/76 e sob fundamento do art. 29 da Instrução CVM no 361/2002.

O controle minoritário é caracterizado em companhias cujo capital social encontra-se pulverizado no mercado e quando um acionista ou grupo de acionistas exerce o poder de controle por meio de ações que representam menos da metade do capital votante ${ }^{72}$, ou seja, tal forma de poder de controle apóia-se em menos de $50 \%$ das ações que conferem poder decisório da companhia. Tal modalidade de poder de controle, também denominada controle de fato, nasce quando inexiste na companhia um acionista controlador majoritário ou quando este não exerça efetivamente o seu controle nas assembléias gerais fazendo prevalecer a sua vontade por meio do exercício do direito de voto; verifica-se que o poder de controle

\footnotetext{
${ }^{70}$ PRADO, Roberta Nioac. Oferta Pública de Ações Obrigatória nas S.A. - Tag Along. $1^{\circ}$ ed. São Paulo: Quartier Latin, 2005. p. 134.

${ }^{71}$ Ibid.

${ }^{72}$ EIZIRICK, Nelson; GAAL, Ariádna B.; PARENTE, Flávia; HENRIQUES, Marcus de Freitas. Mercado de Capitais Regime Jurídico. $2^{\mathrm{a}}$ Ed.Rio de Janeiro: Renovar,2008 p.380.
} 
minoritário não decorre de uma situação de direito, como no poder de controle majoritário, que garanta ao seu titular o controle efetivo e permanente da companhia. ${ }^{73}$

Neste sentido, a Resolução $\mathrm{n}^{\mathrm{o}}$ 401/76 do Conselho Monetário Nacional que regulamentava o revogado art. 254 da Lei das S.A. previa a existência do controle minoritário ao dispor em seu inciso IV:

"Na companhia cujo controle é exercido por pessoa, ou grupo de pessoas, que não é titular de ações que assegurem a maioria absoluta dos votos do capital social, considera-se acionista controlador, para os efeitos desta Resolução, a pessoa, ou grupo de pessoas, vinculadas por acordo de acionistas, ou sob controle comum, que é titular de ações que lhe asseguram a maioria absoluta dos votos dos acionistas presentes nas três últimas Assembléias Gerais da companhia". ${ }^{74}$

Embora não haja previsão expressa na atual Instrução CVM n 361/2002 quanto à existência de tal modalidade de controle, é permitido à CVM obrigar a realização de OPA caso verifique a ocorrência de alienação onerosa de controle acionário minoritário, efetivamente exercido, nos termos do art. 254-A da Lei das S.A. combinado com o art. $29, \S 5^{\circ}$ da referida Instrução. ${ }^{75}$

Outra diferenciação que merece atenção diz respeito ao poder de controle acionário direto e indireto. $\mathrm{O}$ poder de controle acionário direto é aquele resultante da detenção de ações ou participação em acordo de acionistas da companhia de forma direta, ou seja, advém da própria estrutura interna da sociedade e o papel de controlador é estabelecido entre este e os órgãos internos da sociedade. ${ }^{76}$ Tal modalidade de controle é referida no art. 116 da Lei das S.A. e pode ser exercido individual ou coletivamente, podendo ainda ser majoritário ou minoritário.

Assim dispõe o referido artigo:

\footnotetext{
${ }^{73}$ PRADO, Roberta Nioac. Oferta Pública de Ações Obrigatória nas S.A. - Tag Along. $1^{\circ}$ ed. São Paulo: Quartier Latin, 2005. p. 136.

${ }^{74}$ Reitera tal entendimento o Diretor Otavio Yazbek ao proferir seu voto no Processo CVM n ${ }^{\circ}$ 2009/1956 - trazido no último Capítulo.

${ }^{75}$ Ibid.p. 140.

${ }^{76}$ FILHO, Alfredo Lamy; PEDREIRA, José Luiz Bulhões. Direito das Companhias. $1^{\mathrm{a}}$ ed. Rio de Janeiro: Editora Forense, 2009. p. 834.
} 
Art. 116. Entende-se por acionista controlador a pessoa, natural ou jurídica, ou o grupo de pessoas vinculadas por acordo de voto, ou sob controle comum, que:

a) é titular de direitos de sócio que lhe assegurem, de modo permanente, a maioria dos votos nas deliberações da assembléia-geral e o poder de eleger a maioria dos administradores da companhia; e

b) usa efetivamente seu poder para dirigir as atividades sociais e orientar o funcionamento dos órgãos da companhia.

Nota-se que constituem requisitos à caracterização do controle o exercício da maioria dos votos nas deliberações da assembléia geral, o poder de eleger a maioria dos administradores da companhia e o efetivo uso do poder de controle na direção das atividades da sociedade e na orientação dos órgãos da companhia. ${ }^{77}$

A diferenciação dada ao controle indireto resulta da vinculação estabelecida entre duas ou mais sociedades por meio de uma relação hierarquizada na qual a relação de poder não se encontra caracterizada na organização interna da sociedade, mas do grupo, estabelecendo um vínculo de poder entre uma sociedade e os órgãos sociais de outra. ${ }^{78}$ Tal forma de exercício de controle está prevista no art. $243, \S 2^{\circ}$ da Lei das S.A. que define que será "controlada" a sociedade na qual a "controladora," diretamente ou através de outras controladas, detém direitos de sócios que lhe assegurem de forma permanente a preponderância nas deliberações sociais e o poder de eleger a maioria dos administradores; critérios estes estabelecidos também pelo Código Civil que dispõe no seguinte artigo:

“art. 1.098 - É controlada: I - a sociedade de cujo capital outra sociedade possua a maioria dos votos nas deliberações dos quotistas ou da assembléia geral e o poder de eleger a maioria dos administradores; II - a sociedade cujo controle, referido no inciso antecedente, esteja em poder de outra, mediante ações ou quotas possuídas por sociedades ou sociedades por esta já controladas." (grifado)

Ainda no contexto de apresentação das modalidades de controle direto e indireto, a ANATEL (Agência Nacional de Telecomunicações) ao

\footnotetext{
${ }^{77}$ EIZIRICK, Nelson; GAAL, Ariádna B.; PARENTE, Flávia; HENRIQUES, Marcus de Freitas. Mercado de Capitais Regime Jurídico. $2^{\mathrm{a}}$ Ed.Rio de Janeiro: Renovar,2008 p.373.

${ }^{78}$ Ibid.
} 
regulamentar o art. 97 da Lei $n^{\circ} 9.472 / 1996^{79}$ admitiu tal diferenciação no inciso II do art. $1^{\circ}$ da Resolução 101/99:

“Art. $1^{\circ}$ No exercício das funções de órgão regulador e de órgão competente para controle,

prevenção e repressão das infrações da ordem econômica, no setor de telecomunicações, a Anatel, com vistas à apuração de controle e de transferência de controle que sejam objeto de vedação, restrição, limites ou condicionamentos, adotará os seguintes conceitos:

I - Controladora: pessoa natural ou jurídica ou ainda o grupo de pessoas que detiver, isolada ou conjuntamente, o poder de controle sobre pessoa jurídica;

II - Controle: poder de dirigir, de forma direta ou indireta, interna ou externa, de fato ou de direito, individualmente ou por acordo, as atividades sociais ou o funcionamento da empresa.(grifado)"

No mesmo sentido, previu o Regulamento do Novo Mercado ${ }^{80}$ ao conceituar "acionista controlador" e "ações de controle", assim dispondo:

\footnotetext{
"Acionista Controlador" significa o acionista ou o grupo de acionistas vinculado por acordo de acionistas ou sob controle comum que exerça o Poder de Controle da Companhia.

"Ações de Controle" significa o bloco de ações que assegura, de forma direta ou indireta, ao(s) seu(s) titular(es), o exercício individual e/ou compartilhado do Poder de Controle da Companhia.
}

Por fim, apresentadas as modalidades de controle direto e indireto, é válido ressaltar que para fins de aplicação do art. 254-A da lei das S.A e da obrigação prevista no art. 29 da Instrução CVM n ${ }^{\circ}$ 361/2002, devem ser consideradas tanto a forma direta de controle quanto a indireta.

A modalidade de controle acionário indireto é claramente identificada em uma holding, sociedade comercial que controla outra sociedade, constituída na forma de "sociedade por cotas de responsabilidade limitada" ou de "sociedade por ações"81. Tal tipo de

\footnotetext{
79 Tal artigo confere competência à ANATEL quanto a aprovação de atos societários que envolvem a cisão, fusão, a transformação, a incorporação, a redução do capital da empresa ou a transferência de seu controle acionário.

${ }^{80}$ Disponível no endereço eletrônico: http://www.bmfbovespa.com.br/Pdf/RegulamentoNMercado.pdf - acessado em 11.10.2010

${ }^{81}$ PRADO, Roberta Nioac. Oferta Pública de Ações Obrigatória nas S.A. - Tag Along. $1^{\circ}$ ed. São Paulo: Quartier Latin, 2005. p. 144.
} 
sociedade surge quando o acionista controlador ou o grupo de acionistas participantes de grupo de controle transferem o conjunto de ações com direito a voto que detêm para uma nova sociedade.

Dessa forma, "o patrimônio dos acionistas controladores passa a ser as ações ou quotas da sociedade holding e as ações da controlada passam a ser propriedade da holding " ${ }^{~} 82$ que poderá ser criada com o intuito apenas de exercício de controle e a participação no capital social de determinada companhia ou exercer ainda atividade comercial que pode ou não ser relacionada a atividade de sua controlada. Será, portanto, aplicável o art. 254-A da Lei das S.A. quando a holding for alienada e quando tiver sido criada com o propósito de participação em outra sociedade, tendo como requisito a alienação do controle acionário, que deverá ser analisado caso a caso pela CVM.

A última diferenciação quanto às modalidades de poder de controle acionário se refere à forma individual e coletiva ou conjunta, a primeira é aquela exercida por pessoa física ou jurídica, fundo ou universalidade de direitos quando exercida de forma individual, direta ou indiretamente, majoritária ou minoritariamente. ${ }^{83}$

O poder de controle conjunto, em linhas gerais, é aquele que é exercido como fruto da reunião de mais de um acionista na forma de um "acordo de acionistas" - instrumento que usualmente servirá para a conjugação das ações e interesses comuns, configurando assim um poder de controle na medida em que os signatários assumem a obrigação de votarem coletivamente nas matérias atinentes ao poder de controle. Será o acordo de acionistas uma forma de exercício de "acordo de voto em bloco" e o grupo participante do acordo exercerá efetivamente as atribuições inerentes ao poder de controle, de forma a exercer a condução dos negócios da

\footnotetext{
${ }^{82}$ Ibid.

${ }^{83} \mathrm{Ibid}$.
} 
sociedade em conjunto com os acionistas majoritários. ${ }^{84}$ Há ainda a possibilidade de que os acionistas minoritários firmem acordo de votos e passem a constituir um grupo com participação superior a dos então controladores.

Firmado tal acordo de acionistas, a configuração do poder de controle será efetivada desde que: (i) a união dos acionistas represente maioria dos votos nas deliberações da assembléia geral, (ii) que a deliberação seja resultado da expressão da vontade do grupo e não de forma individualizada, (iii) que sejam realizados os devidos procedimentos de deliberações coletiva de forma a registrar a vontade individual dos acionistas e aferir a vontade coletiva expressa por unanimidade ou maioria de votos, (iv) que seja definido o modo de representação do grupo, por um membro ou procurador, nas assembléias gerais e que nesta prevaleçam as deliberações acordadas anteriormente pelos acionistas ou que (v) todos os membros do acordo assumam o compromisso de comparecimento às assembléias gerais e exteriorizem as decisões estabelecidas nas deliberações prévias. $^{85}$

Verifica-se, dessa forma, que a sociedade holding sendo fruto de um acordo de acionistas se torna exemplo do poder de controle conjunto e havendo alteração da participação acionária dos membros do acordo ou alteração do poder de controle da sociedade holding necessária será a apuração da obrigação prevista no art. 254- A da Lei das S.A. ${ }^{86}$

\footnotetext{
${ }^{84}$ EIZIRICK, Nelson; GAAL, Ariádna B.; PARENTE, Flávia; HENRIQUES, Marcus de Freitas. Mercado de Capitais Regime Jurídico. $2^{\mathrm{a}}$ Ed.Rio de Janeiro: Renovar,2008 p.380.

${ }^{85}$ FILHO, Alfredo Lamy; PEDREIRA, José Luiz Bulhões. Direito das Companhias. $1^{\text {a }}$ ed. Rio de Janeiro: Editora Forense, 2009. p. 854.

${ }^{86}$ PRADO, Roberta Nioac. Oferta Pública de Ações Obrigatória nas S.A. - Tag Along. $1^{\circ}$ ed. São Paulo: Quartier Latin, 2005. p. 167.
} 


\subsection{ALIENAÇÃO DO CONTROLE ACIONÁRIO E A IMPORTÂNCIA DA OBRIGATORIDADE DE REALIZAÇÃO DE OPA}

Antes de adentrar o assunto a que este item propõe abordar é de fundamental importância definir o conceito da "alienação do controle acionário". Tal alienação é definida como uma operação de natureza privada e decorre de uma prévia negociação realizada entre o acionista controlador alienante e o adquirente do controle acionário, ${ }^{87}$ cujo objeto é o bloco de ações que conferem o controle da sociedade. Como regra geral, este negócio jurídico deve conter os requisitos de validade previstos no art. 104 do Código Civil que requer agente capaz, objeto lícito (possível, determinado ou determinável) e forma prescrita ou não defesa em lei. ${ }^{88}$ Além disso, a eficácia da alienação será pactuada ${ }^{89}$ sob condição suspensiva ou resolutiva de que o adquirente realize uma oferta pública de aquisição das ações pertencentes aos acionistas minoritários.

O preço estabelecido em tal oferta será no mínimo igual a $80 \%$ do valor pago por ação votante ao controlador e nas mesmas condições acordadas entre as partes, ${ }^{90}$ ou seja, aos demais acionistas detentores de ações com direito a voto ${ }^{91}$ é assegurado o direito de venderem suas ações

\footnotetext{
${ }^{87}$ EIZIRICK, Nelson; GAAL, Ariádna B.; PARENTE, Flávia; HENRIQUES, Marcus de Freitas. Mercado de Capitais Regime Jurídico. $2^{\mathrm{a}}$ Ed.Rio de Janeiro: Renovar,2008 p.583.

${ }^{88}$ PRADO, Roberta Nioac. Oferta Pública de Ações Obrigatória nas S.A. - Tag Along. $1^{\circ}$ ed. São Paulo: Quartier Latin, 2005. p. 120.

${ }^{89}$ Por se tratar de norma com caráter imperativo a realização de OPA obrigatória não dependerá de existência de cláusula expressa no contrato de alienação de controle acionário, caberá à CVM impor a sua realização como condição de eficácia do negócio jurídico por meio do qual o controle acionário é alienado.

90 Ibid. 180.

91 “(...) Nessa condição, encontram-se: (a) os ordinarialistas, sempre; (b) os preferencialistas da classe ou classes em relação às quais o estatuto não subtrai o direito de voto; (c) os preferencialistas com direito a dividendos fixos ou mínimos, se a alienação do controle ocorre quando esses dividendos não foram distribuídos pelo período fixado no estatuto não superior a três exercícios consecutivos (LSA, art. $111, \S^{\circ}$ ). Todos esses acionistas têm direito de vender ao adquirente do controle suas ações, por preço correspondente a pelo menos $80 \%$ do pago ao controlador(...)" In: COELHO, Fabio Ulhoa. O Direito de Saída Conjunta (“Tag Along”) In: Lobo, Jorge (Coord.).Reforma da Lei das Sociedades Anônimas.São Paulo: Forense, 2002.p.480.
} 
em conjunto com o antigo controlador quando da alienação do controle acionário, garantindo o mínimo de $80 \%$ do valor acordado entre as partes. ${ }^{92}$

A obrigação descrita acima se fundamenta no art. 254-A da Lei das S.A. e do art. 29 da Instrução CVM n ${ }^{\circ} 361 / 2002$ que regulamenta as operações de alienação de controle acionário, e é referida pelo termo tag along.

O referido dispositivo legal prevê como faculdade, ao adquirente do controle acionário, oferecer aos acionistas minoritários o pagamento de um prêmio, caso optem por permanecer na sociedade, equivalente à diferença entre o valor de mercado das ações e o valor pago por cada ação que integra o bloco de controle. Porém, tal faculdade não abstém o adquirente do controle quanto à obrigação cogente prevista no art. 254-A - de realização de OPA.

Nos termos do referido artigo, o pagamento do prêmio não constitui procedimento alternativo à oferta pública ${ }^{93}$ que é imperativa e não pode ser afastada pelas partes sem o exame e autorização por parte da CVM, ao contrário do que afirma Luiz Leonardo Cantidiano; segundo este autor a lei faculta ao adquirente do controle de companhia aberta, por meio de decisão unilateral, o pagamento de prêmio aos acionistas minoritários ao invés de lançar a OPA obrigatória, ${ }^{94}$ o que constitui errônea interpretação do texto legal.

Insta salientar que a alienação do controle da companhia poderá ocorrer de forma direta ou indireta ${ }^{95}$, abrangendo assim a legislação as mais diversas formas de controle inclusive aquelas decorrentes de acordos de

\footnotetext{
92 EIZIRICK, Nelson; GAAL, Ariádna B.; PARENTE, Flávia; HENRIQUES, Marcus de Freitas. Mercado de Capitais Regime Jurídico. $2^{\mathrm{a}}$ Ed.Rio de Janeiro: Renovar,2008 p.584.

${ }^{93}$ Ibid. p. 599.

${ }^{94}$ CANTIDIANO, Luiz Leonardo. Características das Ações, Cancelamento de Registro e "Tag Along" In: Lobo, Jorge (Coord.).Reforma da Lei das Sociedades Anônimas.São Paulo: Forense, 2002.p.98.

${ }^{95}$ PARENTE, Norma. Principais inovações introduzidas pela Lei n. 10.303, de 31 de Outubro de 2001, à Lei de Sociedades por ações.In: Lobo, Jorge (Coord.).Reforma da Lei das Sociedades Anônimas.São Paulo: Forense, 2002.p.39
} 
acionistas e de valores mobiliários conversíveis em ações com direito a voto, cessão de direitos de subscrição e outros títulos e direitos relativos a valores mobiliários conversíveis em ações que venham a resultar na alteração de controle acionário da sociedade. ${ }^{96}$ Segundo Modesto Carvalhosa, será obrigatória a realização de OPA quando a alienação do controle acionário se der por meio de sociedade holding, mediante a alienação das ações desta e não da própria companhia visada. ${ }^{97}$

Com relação aos fundamentos de obrigatoriedade da OPA aqui mencionada, é válido reiterar o entendimento a respeito de acionista controlador que é aquele que "exerce, na realidade, o poder, mediante o prevalecimento dos votos que possui. Controlar uma companhia, portanto, é o poder de impor a vontade nos atos sociais e, via de conseqüência, dirigir o processo empresarial, que é o seu objeto" ${ }^{98}$, o que não afasta o importante papel dos minoritários na execução do papel social assim como não diminui os seus direitos enquanto acionistas.

Sob tal premissa, é fundamental que na mudança da titularidade de tal controle os antigos controladores não sejam os únicos beneficiados em tal operação, visto que o patrimônio social decorre de processo de capitalização promovido ou arcado por todos. ${ }^{99}$

Neste sentido, a não extensão ao acionista preferencial da tutela concedida ao acionista com direito a voto, por meio do procedimento de tag along, é criticada pela doutrina já que, em termos patrimoniais, a

\footnotetext{
96 SANTOS, J. A. Penalva. Direito dos minoritários - Alienação de Controle de Companhia Aberta e os Direitos dos Minoritários.Análise do art. 254 da Lei no 6.404 de 1976.In: Lobo, Jorge (Coord.).Reforma da Lei das Sociedades Anônimas.São Paulo: Forense, 2002.p.499.

${ }^{97}$ CARVALHOSA, Modesto. Oferta Pública de Aquisição de Ações.Rio de Janeiro: IBMEC, 1979. p.172.

${ }_{98}^{9}$ Ibid.p. 142 .

${ }^{99}$ Ibid.p. 143 .
} 
contribuição daquele tipo de acionista tem o mesmo valor que a dos demais acionistas. $^{100}$

Ademais, a relação estabelecida entre os minoritários e o controlador da companhia se funda sob um caráter intuitu personae pelo qual é estabelecida confiança entre as partes, podendo a vinculação à companhia ser motivada unicamente pelas características pessoais do controlador.

Dessa forma, é papel da lei garantir a saída dos minoritários, em justas condições, quando da modificação da figura do acionista controlador. $^{101}$

Assegurou, portanto, o legislador por meio da edição do art. 254-A, o direito de desligamento dos acionistas minoritários em relação à sociedade, por meio da OPA, caso não haja manutenção da fidúcia ou do affectio societatis em relação ao novo controlador, impedindo assim uma imposição de relação social decorrente da alteração do controle da companhia. ${ }^{102}$ Segundo a doutrina, a faculdade atribuída ao acionista minoritário em permanecer ou não na companhia advém da adoção do princípio do direito de opinar segundo o qual é dada é dada permissão ao minoritário com relação a escolha de permanecer ou não na companhia e desfazer-se ou não de sua posição. ${ }^{103}$

Outro fundamento que a doutrina encontra para a obrigatoriedade de realização da OPA por alienação de controle acionário se pauta no fato de que o poder de controle é considerado pela lei como um bem, com valor

\footnotetext{
${ }^{100}$ PARENTE, Norma. Principais inovações introduzidas pela Lei n. 10.303, de 31 de Outubro de 2001, à Lei de Sociedades por ações.In: Lobo, Jorge (Coord.).Reforma da Lei das Sociedades Anônimas.São Paulo: Forense, 2002.p.39

${ }^{101}$ EIZIRICK, Nelson; GAAL, Ariádna B.; PARENTE, Flávia; HENRIQUES, Marcus de Freitas. Mercado de Capitais Regime Jurídico. $2^{\mathrm{a}}$ Ed.Rio de Janeiro: Renovar,2008 p.588.

102 Ibid. p. 588.

103 CLEMENTE Júnior, José Alberto.Oferta Pública de Aquisição de Ações na Alienação de Controle de Companhias Abertas - Apontamentos sobre o art. 254 -A da Lei das Sociedades Anônimas: In Revista de Direito Mercantil, Industrial, Econômico e Financeiro.São Paulo: Malheiros.jan-março 2003.Vol. 129. p. 216
} 
próprio $^{104}$, já que admite a sua alienação ${ }^{105}$. Entretanto, o preço acordado na alienação do controle comporta tanto o valor patrimonial desse bem poderes jurídicos atribuídos pelas ações para o exercício do controle da sociedade - assim com outros intangíveis e outros ativos que também pertencem aos acionistas minoritários.

No presente contexto, é válido mencionar o posicionamento doutrinário conhecido como corporate asset, defendido pelos doutrinadores norte -americanos Adolph Berle e Gardiner Means ${ }^{106}$, segundo o qual o valor do poder de controle pertence a toda a companhia já que constitui um ativo social, nesse sentido dispõem:

"the power going with 'control' is an asset with belongs only to the corporation; and the payment for that power, if it goes anywhere, must go into the corporate treasury"

Segundo o entendimento doutrinário aqui referido o prêmio do poder de controle constitui um bem social que advém da lucratividade da sociedade, logo, deve ser dividido entre todos os acionistas com ou sem direito a voto. Nesta esteira de raciocínio, os acionistas preferenciais teriam direito a receber parcela do prêmio de controle quando da alienação de controle acionário da sociedade ${ }^{107}$; posição que não foi adotada pelo legislador brasileiro quando da edição do art. 254-A da Lei das S.A.

Segundo o referido artigo, ao prever a obrigatoriedade de OPA na alienação de controle acionário, a lei assegura somente aos minoritários (com direito a voto) o compartilhamento de parte do "ágio", "sobre -

\footnotetext{
${ }^{104}$ EIZIRICK, Nelson; GAAL, Ariádna B.; PARENTE, Flávia; HENRIQUES, Marcus de Freitas. Mercado de Capitais Regime Jurídico. $2^{\mathrm{a}}$ Ed.Rio de Janeiro: Renovar,2008.p.588.

${ }^{105}$ FILHO, Alfredo Lamy; PEDREIRA, José Luiz Bulhões. Direito das Companhias. $1^{\mathrm{a}}$ ed. Rio de Janeiro: Editora Forense, 2009. p. 1999.

${ }^{106}$ BERLE JR., Adolph A.; MEANS, Gardiner C. The modern corporation and private property. 1.ed. Buffalo: William S. Hein, 2000.p.244.

${ }^{107}$ PRADO, Roberta Nioac. Oferta Pública de Ações Obrigatória nas S.A. - Tag Along. $1^{\circ}$ ed. São Paulo: Quartier Latin, 2005. p. 114.
} 
preço" ou plus apurado na operação. ${ }^{108}$ Seria, portanto, injusto não garantir ao acionista minoritário o direito de vender suas ações conjuntamente com o antigo controlador já que é titular do mesmo tipo de ação. ${ }^{109} \mathrm{O}$ fundamento para a apropriação parcial deste plus por parte dos acionistas minoritários funda-se indiretamente no princípio da valorização da responsabilidade do controlador já que, ao impor apenas $80 \%$ do valor pago às ações integrantes do bloco de controle, o legislador considerou o ônus do controlador com relação às responsabilidades assumidas em razão da detenção do poder de controle da companhia. ${ }^{110}$

Nota-se que o procedimento de tag along, previsto no art. 254- A da Lei das S.A., admite a existência de valores subjetivos que compõem o poder de controle acionário, ou seja, reconhece o legislador o valor econômico próprio do poder de controle e impede que este seja apropriado exclusivamente pelo transferente do controle.

Como consequiência de tal regulamentação, gera-se uma diminuição quanto aos prejuízos que a modificação do controle possa trazer à liquidez das ações detidas pelos minoritários ${ }^{111}$ na medida em que adota o princípio de igualdade de tratamento $^{112}$ dos acionistas, detentores de mesma espécie e classe de ações, ainda que de forma mitigada, ${ }^{113}$ já que o direito de venda conjunta das ações não alcança a todos os acionistas, limita - se aqueles que

\footnotetext{
${ }^{108} \mathrm{O}$ reconhecimento da existência de valores que ultrapassam o valor das ações, no bloco de controle alienado, ensejou a edição do art. 254 da Lei $\mathrm{n}^{\circ}$ 6.404/76 como forma de assegurar tratamento igualitário aos acionistas minoritários - tal artigo foi revogado pelo art. $6^{\circ}$ da Lei $n^{\circ}$ 9.457/97, como registrado no Cap. I.

${ }^{109}$ PARENTE, Norma. Principais inovações introduzidas pela Lei n. 10.303, de 31 de Outubro de 2001, à Lei de Sociedades por ações.In: Lobo, Jorge (Coord.).Reforma da Lei das Sociedades Anônimas.São Paulo: Forense, 2002.p.39

${ }^{110}$ CLEMENTE Júnior, José Alberto.Oferta Pública de Aquisição de Ações na Alienação de Controle de Companhias Abertas - Apontamentos sobre o art. 254 -A da Lei das Sociedades Anônimas: In Revista de Direito Mercantil, Industrial, Econômico e Financeiro.São Paulo: Malheiros.jan-março 2003.Vol. 129. p. 216.

${ }^{111}$ ABRÃO, Carlos Henrique. Direito das Minorias. In: Lobo, Jorge (Coord.).Reforma da Lei das Sociedades Anônimas.São Paulo: Forense, 2002.p.270.

${ }_{112}$ Tal princípio fundamentou o revogado art. 254 da Lei das S.A., regulado pela Resolução 401, nos termos do qual o adquirente do controle acionário era obrigado a formular uma OPA da companhia aberta, pelo mesmo preço e nas mesmas condições contratadas com o acionista controlador antigo.

${ }^{113}$ PRADO, Roberta Nioac. Oferta Pública de Ações Obrigatória nas S.A. - Tag Along. $1^{\circ}$ ed. São Paulo: Quartier Latin, 2005. p. 109.
} 
possuem ações com direito a voto e garante que as ações sejam vendidas a um preço $20 \%$ menor do que o valor atribuído por ação pertencente ao bloco de controle. ${ }^{114}$

O princípio aqui referido é efetivamente adotado atualmente nas companhias abertas autorizadas a negociarem seus valores mobiliários no Novo Mercado da Bovespa que veda a emissão de ações preferenciais às companhias listadas em tal segmento e obriga a extensão de $100 \%$ do preço pago às ações de controle quando de sua alienação. ${ }^{115}$

Outro fundamento citado pela doutrina que justifica o procedimento de tag along, previsto no art. 254-A da Lei das S.A., funda-se no princípio da proteção à poupança popular ${ }^{116}$, já que os recursos utilizados para o processo de capitalização da companhia decorrem dos investimentos dos acionistas que atendem a um apelo público e confiam seus recursos a um terceiro. Adotando-se a premissa de que o sucesso de tais investimentos depende de um terceiro a quem foi depositada confiança, os minoritários carecem de adequada proteção.

Como exposto em capítulo anterior, necessário será o registro na CVM que exercerá o seu papel de controle e fiscalização dos atos societários a fim de assegurar o devido cumprimento legal e normativo previsto no art. 254-A e na Instrução CVM no 361/2002. Deverá, portanto, assegurar esta autarquia o cumprimento do direito dos minoritários de desvincula-se da sociedade caso haja alteração nas bases de controle na companhia na qual estabeleceu o affectio societatis, sendo ainda garantido a

\footnotetext{
114 Ibid.

115 Ibid.p.303.

116 CLEMENTE Júnior, José Alberto.Oferta Pública de Aquisição de Ações na Alienação de Controle de Companhias Abertas - Apontamentos sobre o art. 254 -A da Lei das Sociedades Anônimas: In Revista de Direito Mercantil, Industrial, Econômico e Financeiro.São Paulo: Malheiros.jan-março 2003.Vol. 129. p. 215.
} 
estes o direito de participar do prêmio ou ágio adquirido pelo antigo controlador quando na alienação do controle acionário ${ }^{117}$.

\title{
2.3 Requisitos para a exigibilidade de realização de OPA em caso de alienação de controle: entendimento da Comissão de Valores Mobiliários
}

A caracterização da alienação de controle acionário e o posterior surgimento da obrigatoriedade de realização da OPA dependem da análise casuística das operações societárias por parte da CVM. Esta autarquia reiterou, por meio dos julgados realizados por parte de seu Colegiado, os requisitos consagrados em termos legais e normativos que tornam obrigatória a realização de OPA em caso de alienação do controle acionário, a seguir apresentadas

Inicialmente cumpre aqui apresentar a caracterização da alienação de controle conferida nos termos da Lei das S.A. e da Instrução CVM n ${ }^{\circ}$ 361/2002, respectivamente:

\begin{abstract}
“Art. 254-A. (...) $§ 1^{\circ}$ Entende-se como alienação de controle a transferência, de forma direta ou indireta, de ações integrantes do bloco de controle, de ações vinculadas a acordos de acionistas e de valores mobiliários conversíveis em ações com direito a voto, cessão de direitos de subscrição de ações e de outros títulos ou direitos relativos a valores mobiliários conversíveis em ações que venham a resultar na alienação de controle acionário da sociedade. (Incluído pela Lei ${ }^{\circ}$ 10.303, de 2001) (...)"
\end{abstract}

"Artigo 29 (...) $\S 4^{\circ}$ Para os efeitos desta instrução, entende-se por alienação de controle a operação, ou o conjunto de operações, de alienação de valores mobiliários com direito a voto, ou neles conversíveis, ou de cessão onerosa de direitos de subscrição desses valores mobiliários, realizada pelo acionista controlador ou por pessoas integrantes do grupo de controle, pelas quais um terceiro, ou um conjunto de terceiros representando o mesmo interesse, adquira o poder de controle da companhia, como definido no art. 116 da Lei 6.404/76. (...)"

\footnotetext{
${ }^{117}$ EIZIRICK, Nelson; GAAL, Ariádna B.; PARENTE, Flávia; HENRIQUES, Marcus de Freitas. Mercado de Capitais Regime Jurídico. $2^{\mathrm{a}}$ Ed.Rio de Janeiro: Renovar,2008 p.589.
} 
Verifica-se que a alienação de controle da companhia não pode ser interpretada como uma mera cessão de um bloco de ações e sim da verdadeira transferência do poder daquele que de fato controla e dirige a sociedade. Dessa forma, tal alienação “(...) pressupõe também, e necessariamente, a alienação de um poder sobre os negócios da companhia"118

Da leitura dos dispositivos acima referidos e com base na interpretação dada por parte do Colegiado da CVM no julgamento de processos submetidos a este órgão, a caracterização da alienação de controle acionário de uma companhia aberta poderá ter como objeto ações integrantes do bloco de controle ou vinculadas por acordo de acionistas, valores mobiliários conversíveis em ações com direito a voto, direitos de subscrição de ações ou outros títulos ou direitos relativos a valores mobiliários conversíveis em ações ${ }^{119}$.

No mesmo sentido, entende Carlos Augusto Junqueira ao afirmar que a transferência de controle independe da existência de um bloco uno e imutável de controle, o que importa é que este tenha sido transferido ${ }^{120}$, dessa forma, necessária é a análise pela CVM a fim de averiguar a existência ou não de alienação de controle acionário já que esta não implica na transferência de única modalidade de valor mobiliário, ou seja, de ações.

Vale lembrar que, em qualquer situação, o obrigatoriedade de realização de oferta pública só ocorrerá quando da efetiva transferência do poder de controle, ou seja, cabe aqui distinguir a alienação de ações em

\footnotetext{
${ }^{118}$ OLIVEIRA, Fernando Albino de. A alienação do controle societário na Lei das S.A. In: JAIRO SADDI (org.). Fusões e Aquisições: aspectos jurídicos e econômicos.São Paulo: IOB.2002.p.227228.

119 ANDREZO, Andrea Fernandes. A alienação de controle de companhia aberta e a recente reforma da legislação societária - Efetivo Avanço? In: Revista de Direito Mercantil, Industrial, Econômico e Financeiro. São Paulo: Malheiros, n.130 - abril -junho 2003.p.161-179.

${ }^{120}$ SIQUEIRA, Carlos Augusto Junqueira de. Transferência do controle acionário: interpretação e valor. Rio de Janeiro: FMF Ed., 2004. p. 64.
} 
potência $^{121}$ e a alienação de ações efetiva, - os valores mobiliários transferidos e que conferem direito de voto só serão considerados para fins de alienação de controle quando houver a subscrição ou conversão em ações com direito de voto, ao contrário, será considerada uma mera transferência de ações em potência e portanto sem importância para a verificação da obrigação prevista nos referidos artigos.

Pela interpretação literal de tais dispositivos depreende-se ainda que a alienação a que se referem os artigos ocorrerá das seguintes formas (i) de forma direta ou indireta, (ii) de uma única vez ou por etapas,(iii) por aquele que detiver o controle acionário ou por aqueles que integrem o grupo de controle a um terceiro não integrante do controle e (v) de forma onerosa, necessariamente.

A alienação de controle acionário direta ocorre quando o acionista controlador ou aqueles que integrem bloco de controle transferem onerosamente a um terceiro que adquire então a posição de controlador. ${ }^{122} \mathrm{~A}$ forma indireta é caracterizada quando ocorre a alienação de controle de companhia que atua como controladora de determinada companhia aberta $^{123}$. O controle indireto é identificado pela vinculação de duas ou mais sociedades cuja relação estabelecida entre elas é hierarquizada, ou seja, uma tem o poder de controlar, de fato ou de direito, a outra. A estrutura de poder indireto estabelecida entre os grupos de sociedades implicam em alienação de controle indireto quando o poder da sociedade controladora é alienado diretamente. $^{124}$ Exemplo mais comum de alienação de controle indireto decorre das relações que envolvem uma sociedade holding ${ }^{125}$. Em tal

\footnotetext{
${ }^{121}$ FILHO, Alfredo Lamy; PEDREIRA, José Luiz Bulhões. Direito das Companhias. $1^{\text {a }}$ ed. Rio de Janeiro: Editora Forense, 2009. p. 2012.

${ }^{122}$ ANDREZO, Andrea Fernandes. A alienação de controle de companhia aberta e a recente reforma da legislação societária - Efetivo Avanço? In: Revista de Direito Mercantil, Industrial, Econômico e Financeiro. São Paulo: Malheiros, n.130 - abril -junho 2003.p.161-179.

${ }^{123}$ Ibid.

${ }^{124}$ FILHO, Alfredo Lamy; PEDREIRA, José Luiz Bulhões. Direito das Companhias. $1^{\text {a }}$ ed. Rio de Janeiro: Editora Forense, 2009. p. 2017.

${ }^{125}$ CARVAlHOSA, Modesto. Oferta Pública de Aquisição de Ações.Rio de Janeiro: IBMEC, 1979. p. 147.
} 
sentido e assumindo a consideração das formas direta e indireta de controle, dispõem as palavras do Diretor da CVM Eli Loria ao julgar o Processo CVM n ${ }^{\circ}$ RJ- 2007-7230, no qual foi analisada a aplicabilidade do art.254-A da Lei das S.A.:

"Cabe verificar, portanto, se ocorreu, a par da alienação de valores mobiliários, direta ou indireta, também a aquisição de um poder sobre as atividades da companhia, a luz do $\S 4^{\circ}$ do art. 254-A.

A Lei 6.404/76 em seu art. 254-A trata da alienação, direta ou indireta, do controle de companhia aberta, e o faz segundo um objeto de análise bastante lato, porquanto indica as operações com valores mobiliários que importem na

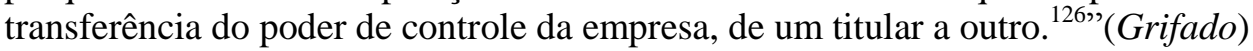

No mesmo sentido dispõe o voto pelo ex- diretor da CVM Pedro Oliva no julgamento do Processo CVM No RJ-2005/4069 pelo qual a Companhia Brasileira de Distribuição interpôs recurso ao Colegiado contra decisão da Superintendência de Registro de Valores Mobiliários (SRE) que determinou a obrigatória realização de OPA:

"Esse significado inclui, dentre as operações que dão causa à oferta pública, não só a alienação de ações agrupadas em sociedade holding, mas, também, a inclusão de acertos contratuais que impliquem a transferência dos direitos políticos e econômicos do valor mobiliário, sem a transferência da ação (a conferência de usufruto vitalício de voto e dividendos mediante contraprestação em dinheiro ou a celebração de acordo de acionistas, regulando voto e distribuição de dividendos, por exemplo), tenha esse acordo sido celebrado para se evitar a realizar a oferta pública ou mesmo com vistas a um outro fim lícito. Como isso, para a aplicação do art. 254-A, se em uma operação não se verificar a transferência de valores mobiliários que implique alienação de controle, deve-se analisar se essa alienação ocorreu de forma indireta (i.e., mediante acordos que resultem na transferência de poder político e econômico desses valores mobiliários). ${ }^{127 "}$ ( Grifado)

Consoante ao disposto no art. 254-A, a alienação de controle acionário poderá ser realizada por ato único formalizado por meio de contrato de transferência onerosa do poder de controle assim como poderá

\footnotetext{
${ }^{126}$ Termos contidos no voto do Diretor Relator Eli Loria, proferido na Reunião Extraordinária do Colegiado de 11.3.2007 (Reg.5533/07) e extraídos do sítio da CVM (www.cvm.gov.br).

127 Termos contidos no voto do Diretor Relator Pedro Oliva Marcilio de Sousa, proferido na Reunião do Colegiado de 11.4.2006 (Reg.4788/05) e extraídos do sítio da CVM (www.cvm.gov.br).
} 
ser caracterizada por atos isolados, em etapas, que reunidos caracterização a efetiva alienação de poder de controle acionário. Como ilustrado no recente caso que envolveu a alienação de controle da Sadia pela Perdigão. A operação foi organizada em duas etapas e ao fim $100 \%$ do capital social da Sadia passaria a ser detido pela nova sociedade, BRF Brasil Foods. O relatório apresentado pela Superintendência de Relações com Empresa (SEP) dispôs no seguinte sentido:

"Trata-se de operações de incorporação de ações da HFF Participações S.A. ("HFF") e da Sadia S.A. ("Sadia"), na BRF Brasil Foods S.A. ("BRF"), através das quais esta companhia se tornará controladora, direta e indireta, da Sadia, nos termos do Acordo de Associação firmado pelas três companhias em 19.05.2009.

A operação está organizada em duas etapas, ao fim das quais $100 \%$ do capital social da Sadia passará a ser detido, direta ou indiretamente, por BRF, nova denominação da Perdigão S.A. Na primeira etapa, as ações pertencentes aos integrantes do bloco de controle da Sadia foram conferidas ao capital social da HFF (empresa veículo), recebendo os titulares em questão, por cada ação ON da SADIA, uma ação do capital social da HFF. Ato contínuo, as ações de HFF foram incorporadas pela BRF de acordo com uma relação de troca de 0,166247 ação da BRF para cada ação ON da HFF. A segunda etapa envolve a incorporação das ações pertencentes aos minoritários da SADIA pela já controladora BRF, segundo uma relação de troca de 0,132998 ação da BRF para cada ação ON ou PN de emissão da Sadia. Desse modo, a operação contempla relações de troca diferenciadas, sendo a relação em favor dos acionistas que integravam originalmente o bloco de controle da Sadia e de pessoas a eles ligadas mais vantajosa. ${ }^{128}(\ldots)$ ". (Grifado)

No referido julgado, segundo entendimento do diretor da CVM Marcos Barbosa Pinto, a alienação de controle acionário decorreu de duas etapas: primeiro, as ações de uma sociedade holding dos controladores da Sadia são incorporadas ${ }^{129}$ pela BRF; em seguida, as ações dos demais acionistas da própria Sadia são incorporadas pela BRF.

\footnotetext{
${ }^{128}$ Termos contidos no voto do Diretor Marcos Barbosa Pinto, proferido na Reunião do Colegiado de 11.8.2009 (Reg.6584/09) e extraídos do sítio da CVM (www.cvm.gov.br).

129 Vale aqui observar que o requisito utilizado para a análise da obrigatoriedade de formulação de OPA foi a alienação de controle acionário resultante dos atos societários aqui mencionados e não pela mera operação de incorporação cuja obrigação de realização de OPA inexiste no texto legal.
} 
Tal exemplificação prática demonstra a admissão por parte da CVM que a alienação de controle acionário não decorre necessariamente de ato uno e indivisível. Ainda que realizados de forma isolada, a CVM deve identificar o intuito buscado pelos atos, realizando uma análise casuística e conjunta dos atos societários conexos que possuem identidade de participantes e a efetiva alteração do controle acionário ${ }^{130}$. Devendo, portanto, esta autarquia, de toda forma, proteger os interesses dos acionistas minoritários ainda que os atos societários conjuntos "mascarem" uma verdadeira alienação de controle acionário com a utilização de argumentos como o "mero reforço de controle" por parte dos terceiros - adquirentes de controle.

Outro requisito importante para a caracterização da alienação de controle acionário importa na existência de um terceiro adquirente do controle, ou seja, o legislador aqui se referiu ao que a doutrina conceitua como aquisição originária de controle e a aquisição derivada de controle, sendo somente a segunda modalidade importante para fins de aplicação do art. 254-A da Lei das S.A. A aquisição originária de controle decorre do nascimento de um poder de controle acionário que inexistia anteriormente, em tal situação há "adquirente" porém inexiste "alienante", o que descaracteriza a "alienação" e desobriga o adquirente quanto a formulação de OPA aos minoritários ${ }^{131}$.

A aquisição derivada é aquela na qual figura o terceiro adquirente além do alienante o que denota a existência de um controle prévio exercido pelo controlador ou membro do grupo controlador e que o transferem a um terceiro, alheio ao grupo de controle, ou terceiros vinculados pela intenção de exercício do poder de controle. ${ }^{132}$ Para Carlos Augusto Junqueira:

\footnotetext{
${ }^{130}$ PRADO, Roberta Nioac. Oferta Pública de Ações Obrigatória nas S.A. - Tag Along. $1^{\circ}$ ed. São Paulo: Quartier Latin, 2005. p. 200.

${ }^{131}$ Ibid.p. 222.

${ }^{132}$ FILHO, Alfredo Lamy; PEDREIRA, José Luiz Bulhões. Direito das Companhias. $1^{\text {a }}$ ed. Rio de Janeiro: Editora Forense, 2009. p. 2014.
} 
"A transferência de controle é a operação que resulta na efetiva substituição do poder de dominação na sociedade. É quando esse poder muda, efetivamente, de mãos, por qualquer forma ou meio oneroso, fazendo incidir a obrigatoriedade de efetuar oferta pública de compra das ações pertencentes aos acionistas minoritários. ${ }^{133, " ~(G r i f a d o) . ~}$

Expressa entendimento da CVM, quanto ao requisito de aquisição derivada à caracterização de alienação de controle, o trecho do voto do diretor Eli Loria no Processo CVM nº RJ-2007-7230, acima referido, que assim esclarece:

"Destarte, para que ocorra a alienação do controle, necessário que haja mudança na titularidade do poder de controle, sendo fundamental, portanto, a presença de novo controlador. Tal questão ganha ainda mais perspectiva se verificarmos que o próprio fundamento da OPA, a sua razão de ser, está no resguardo do direito dos acionistas não controladores de se retirarem de uma companhia que, uma vez controlada por pessoa diversa da que o fazia antes, já não representa seus interesses." (Grifado)

“(...) Daí decorre, no meu entender, que a venda de participação a uma pessoa já integrante do bloco de controle não implica, em princípio, na obrigatoriedade de realização de oferta pública (...) $)^{134,}$

No mesmo sentido, dispõe o voto do ex- diretor da CVM Marcelo Trindade ao tratar dos requisitos para a caracterização da alienação do controle acionário dentre eles a aquisição derivada, ilustrada (ii) e (iii):

"O conceito da Instrução antecipa a interpretação da lei pela CVM quanto a alguns pontos relevantes: (i) a alienação pode-se dar por operação isolada ou por um conjunto de operações, dificultando a fraude à lei pelo fracionamento do negócio de aquisição; (ii) a alienação tem que ser realizada por quem já seja, então, acionista controlador ou por pessoa integrante do grupo de controle; $\mathrm{e}$

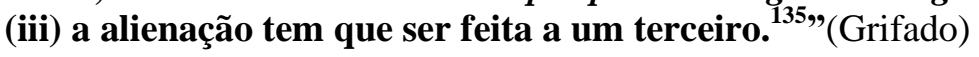

\footnotetext{
${ }^{133}$ SIQUEIRA, Carlos Augusto Junqueira de. Transferência do controle acionário: interpretação e valor. Rio de Janeiro: FMF Ed., 2004. p. 64.

${ }^{134}$ Termos contidos no voto do Diretor Relator Eli Loria, proferido na Reunião Extraordinária do Colegiado de 11.3.2007 (Reg.5533/07) e extraído do sítio da CVM (www.cvm.gov.br).

135 Termos contidos no voto do Diretor Marcos Pinto Barbosa, proferido na Reunião Extraordinária do Colegiado de 11.3.2007 (Reg.5533/07) e extraído do sítio da CVM (www.cvm.gov.br).
} 
Nesta esteira de raciocínio, a caracterização da alienação do poder acionário se dará quando a sociedade controlada passe a ter novo controlador ou bloco de controle ${ }^{136}$. Lembrando que a simples mudança estrutural do bloco de controle, sem que haja mudança quanto ao poder diretivo da sociedade, não ensejará em efetiva alienação de controle acionário da companhia. ${ }^{137}$ Não importando, dessa forma, para a incidência do art. 254-A, a aquisição originária do poder de controle acionário.

Por fim, a caracterização da alienação do controle acionário, prevista no art. 254-A da Lei das S.A., requer-se ainda que a transferência do poder de controle seja realizada de forma onerosa, como reitera o trecho do voto, ao Processo acima referido, apresentado pelo diretor Eli Loria:

\begin{abstract}
"Assim, as características da alienação do controle acionário que obrigam a realização de oferta pública são duas: (i) que a titularidade do poder de controle seja conferida a pessoa diversa do anterior detentor do controle e (ii) que a transferência de ações do bloco de controle seja realizada a título oneroso, com ônus e bônus tanto para o alienante quanto para o adquirente.
\end{abstract}

Claro que a análise de uma operação de alienação de controle é feita caso a caso, assim demonstrado pela redação do $\S 5^{\circ}$ do art. 29 da Instrução CVM n ${ }^{\circ} 361 / 02$ que informa aos entes jurisdicionados que a CVM poderá impor a realização de OPA sempre que verificar ter ocorrido a alienação onerosa do controle de companhia aberta."(Grifado).

Dessa forma conclusiva ao entendimento aqui trazido, a forma gratuita de transferência, como a doação ou transferência hereditária, não ensejará na obrigação de realização de OPA aos minoritários. ${ }^{138}$

Por fim, insta salientar que a onerosidade aqui mencionada será caracterizada ainda que o valor pago aos minoritários seja menor ${ }^{139}$ do que

\footnotetext{
136 ANDREZO, Andrea Fernandes. A alienação de controle de companhia aberta e a recente reforma da legislação societária - Efetivo Avanço? In: Revista de Direito Mercantil, Industrial, Econômico e Financeiro. São Paulo: Malheiros, n.130 - abril -junho 2003.p.161-179.

${ }^{137}$ EIZIRICK, Nelson; GAAL, Ariádna B.; PARENTE, Flávia; HENRIQUES, Marcus de Freitas. Mercado de Capitais Regime Jurídico. $2^{\text {a }}$ Ed.Rio de Janeiro: Renovar,2008 p.593.

${ }^{138}$ FILHO, Alfredo Lamy; PEDREIRA, José Luiz Bulhões. Direito das Companhias. $1^{\text {a }}$ ed. Rio de Janeiro: Editora Forense, 2009. p. 2012.
} 
aquele atribuído às ações negociadas no mercado secundário ${ }^{140}$ ou quando não houver pagamento de qualquer tipo de ágio ao adquirente do controle $^{141}$, uma vez que a legislação não faz qualquer tipo de ressalva quanto à obrigatoriedade de realização de OPA em tais situações.

139 Aqui vale esclarecer que o preço menor, ocasionado pela iliquidez das ações decorrente da alienação de controle, não pode ser óbice ao direito de saída dos minoritários já que constitui garantia que não pode ser afastada.

${ }^{140}$ EIZIRICK, Nelson; GAAL, Ariádna B.; PARENTE, Flávia; HENRIQUES, Marcus de Freitas. Mercado de Capitais Regime Jurídico. $2^{\text {a }}$ Ed.Rio de Janeiro: Renovar,2008 p.595.

141 ANDREZO, Andrea Fernandes. A alienação de controle de companhia aberta e a recente reforma da legislação societária - Efetivo Avanço? In: Revista de Direito Mercantil, Industrial, Econômico e Financeiro. São Paulo: Malheiros, n.130 - abril -junho 2003.p.161-179 


\section{CAPÍTULO 3 - ANÁLISE DO CASO TIM PARTICIPAÇÕES S.A.}

As noções anteriormente quanto aos requisitos que caracterizam a obrigatoriedade de realização de OPA, nos termos do art. 254-A da Lei das S.A e do art. 29 da Instrução CVM n ${ }^{\circ}$ 361/2002, possuem o intuito de instrumentalizar a compreensão dos atos societários que envolveram a alienação de controle da sociedade brasileira Tim Participações S.A. em virtude da transferência de controle de sua controladora indireta Telecom Itália.

A seguir será feito breve relato da operação, nos termos do relatório da reunião extraordinária do Colegiado da CVM de 15.07.2009, Reg. no 6360/08 relativa ao Processo CVM nº RJ-2009/1956 cujo objeto de julgamento foi "RECURSO CONTRA DECISÃO DA SRE- OPA DE TIM PARTICIPAÇÕES S.A. ${ }^{142}$

O Referido processo dispõe sobre recurso apresentado por Telco S.p.A. ("Telco") contra decisão do Superintendente de Registro de Valores Mobiliários ("SRE") apresentada nos autos do Processo administrativo CVM n ${ }^{\circ}$ RJ2007/14344, que concluiu pela obrigatoriedade de realização de oferta pública de aquisição ("ㅇA") de ações de emissão da TIM Participações S.A. ("TIM Participações" ou "Companhia") pela Telco, como requisito para a alienação indireta do controle da Companhia, nos termos do art. 254-A da Lei no 6.404/1976 ("LSA").

A descrição societária das companhias envolvidas, segundo relatório supramencionado, encontra-se caracterizada da seguinte maneira: A sociedade TIM Participações S.A., companhia aberta, titular de $100 \%$ das ações das sociedades brasileiras TIM Celular S.A. e TIM Nordeste S.A. é controlada diretamente pela TIM Brasil Serviços e Participações S.A.

\footnotetext{
${ }^{142}$ Disponível no sítio da CVM (www.cvm.gov.br)
} 
("TIM Brasil"), titular de ações ordinárias que ${ }^{143}$ representam $81,24 \%$ do seu capital votante. O capital da TIM Brasil é integralmente detido pela Telecom Italia International NV, sociedade holandesa que, por sua vez, é subsidiária integral da Telecom Italia S.p.A., companhia aberta italiana ("Telecom Italia").

Os investidores alegam que o controle de fato da Telecom Italia e, por consequência, o controle indireto da TIM Participações teria sido transferido de forma onerosa para a Telco em operação realizada na Itália em 2007 e, portanto, solicitaram que fosse determinada a realização, pela Telco, de OPA de ações ordinárias de emissão da TIM Participações.

A sociedade Olimpia S.p.A. ("Olimpia") era a principal titular de ações ordinárias da Telecom Italia, com participação equivalente a 17,99\% do seu capital ordinário. O capital da Olimpia era dividido entre, de um lado, Pirelli \& C. S.p.A. ("Pirelli"), titular de $80 \%$ do capital, e, de outro, Edizione Holding S.p.A. (substituída por Sintonia S.p.A.) e Edizione Finance International S.A. (cujo nome foi alterado para Sintonia S.A.), as quais eram titulares dos demais $20 \%$ do capital (em conjunto, "Sintonia").

Em 28.04.2007, Assicurazioni Generali S.p.A., Sintonia S.A., Intesa Sanpaolo S.p.A., Mediobanca S.p.A. e Telefónica S.A. ("Telefónica") celebraram (i) um Co-Investment Agreement, no qual acordaram sobre a sua participação na Telco, sociedade que seria utilizada como veículo para a compra de $100 \%$ do capital da Olimpia; e (ii) um Acordo de Acionistas referente à sua participação na Telco.

O Co-Investment Agreement e o Acordo de Acionistas previam que a Telefónica e a Telecom Italia seriam administradas de forma autônoma e

\footnotetext{
${ }^{143}$ Segundo dados constantes no MEMO/SRE/GER-1/Nº $164 / 2008$ os seguintes acionistas figuram no pólo ativo da reclamação à CVM: JGP Hedge Fundo de Investimento Multimercado, Gávea Brasil Fundo de Investimento Multimercado, Hedging-Griffo Verde Equity Master Fundo de Investimento Multimercado, HG Verde Master Fundo de Investimento Multimercado, HG Top Fundo de Investimento Multimercado, HG Top 30 - Fundo de Investimento Financeiro, HG Star Fundo de Investimento Multimercado e HG Carteira Administrada Real Fundo de Investimento Financeiro.
} 
independente. Contudo, as partes reconheceram que, sem prejuízo da independência e autonomia das suas administrações, o investimento na Telco implicava visão e perspectiva estratégicas. Assim, as partes se comprometeram a considerar quaisquer iniciativas estratégicas que as administrações da Telefónica e da Telecom Italia pudessem desenvolver em conjunto, na sua independência e autonomia.

Em 04.05.2007, o referido grupo de investidores celebrou contrato de compra e venda de ações com os acionistas da Olimpia (Pirelli e Sintonia), no qual acordaram sobre a compra da totalidade do capital da Olimpia. A compra foi aperfeiçoada em 25.10.2007, após a obtenção das aprovações cabíveis ("Operação").

No mesmo dia (25.10.2007), ações ordinárias da Telecom Italia equivalentes a 5,6\% do capital votante foram contribuídas ao capital da Telco pela Mediobanca S.p.A. e pela Assicurazioni Generali S.p.A.

Como resultado da Operação e da contribuição ao capital acima indicada, a Telco passou a ser (i) diretamente titular de $100 \%$ do capital da Olimpia, que, por sua vez, tinha $17,99 \%$ do capital da Telecom Italia; e (ii) diretamente titular de 5,6\% do capital da Telecom Italia, conforme quadro abaixo:

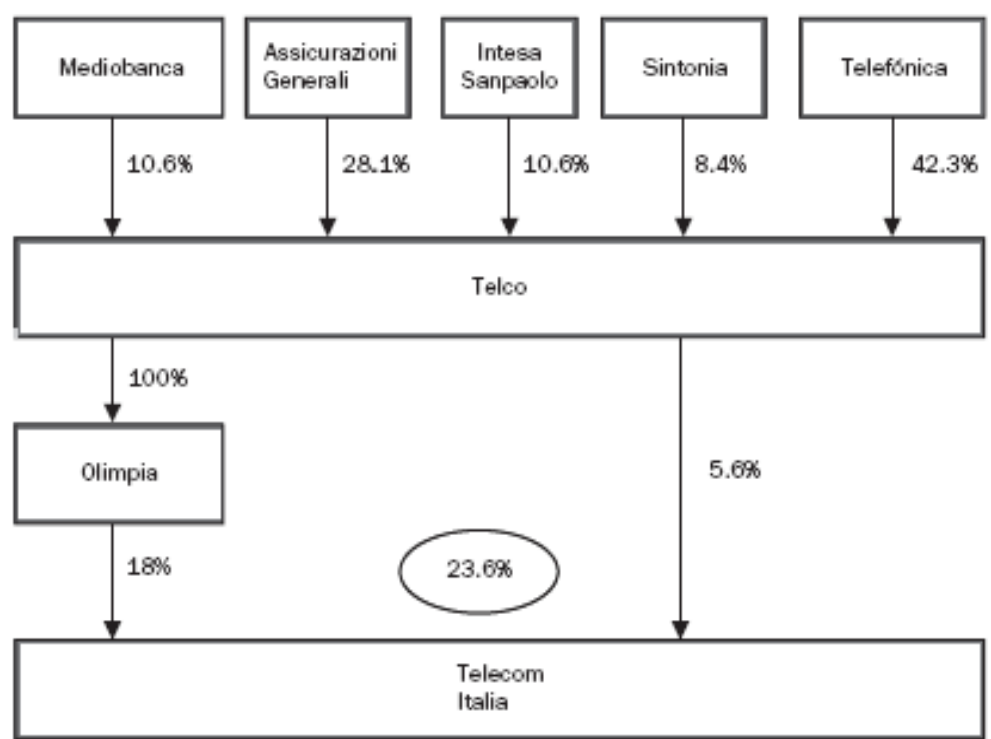


Em 18.12.2007, a Olimpia foi incorporada pela Telco, passando a Telco a ser titular diretamente de participação equivalente a 23,59\% do capital votante da Telecom Italia. Em 20.03.2008, a Telco adquiriu nova participação na Telecom Italia, tornando-se titular de 24,5\% do capital.

O capital da Telco é formado da seguinte forma: ações Classe A (atualmente detidas por Assicurazioni Generali S.p.A. Sintonia S.A., Intesa Sanpaolo S.p.A. e Mediobanca S.p.A.) e Classe B (atualmente detidas pela Telefónica), as quais, em regra, conferem os mesmos direitos econômicos e administrativos aos seus titulares.

Tal operação foi apresentada à Agência Nacional de Telecomunicações (ANATEL) que admitiu a existência de uma alienação indireta de controle de Telecom Italia S.p.A. por parte da Telefônica S.A.

Os argumentos apresentados pelos investidores reclamantes Olímpia concluem que Olimpia exercia o controle de fato de Telecom Itália que, por sua vez, detinha controle absoluto de todas as sociedades integrantes do Grupo Telecom Itália, dentre elas, a TIM Participações S.A.

Antes da operação, Pirelli era titular de $80 \%$ do capital de Olímpia, apesar desta possuir apenas $17,99 \%$ do capital ordinário da Telecom Italia. Alegam a existência de acordo de acionistas da Telecom Italia, celebrado pelo prazo de 3 anos, a contar de 18/10/2006, do qual foram partes Pirelli, Edizione, Olimpia, Assecurazioni Generalli S.p.A. e Mediobanca S.p.A. por meio do qual as signatárias, titulares de $23 \%$ do capital da companhia italiana, manifestavam o propósito de assegurar o desenvolvimento industrial da companhia na Itália e no exterior.

Ademais, afirmam que Olimpia elegeu de 4/5 dos membros do Conselho de Administração nas últimas assembléias gerais de Telecom Itália ocorridas em momento anterior à alienação de controle à Telco. 
Até 2001, o controle de Olimpia teria sido exercido por Olivetti e posteriormente transferido para Pirelli (que passou a controlar a Telecom Italia por meio de Olimpia), tendo sido por último transferido para Telco que pagou expressivo prêmio pelo poder que adquiriu (cerca de $41 \%$ sobre o valor de mercado).

Alertam os investidores reclamantes que, nos termos do art. 2359 do Código Civil Italiano, para a caracterização das sociedades controladas e coligadas há admissão do poder de controle de fato, situação em que, apesar de não deter a maioria das ações com direito a voto, certo acionista ou grupo de acionista é capaz de exercer uma influência dominante na assembléia. Afirmam ainda que o percentual de 30\% estabelecido pela lei italiana para a realização de oferta pública é critério de presunção de controle, não constituindo requisito fundamental para a sua caracterização.

Como forma de ilustrar seus argumentos os reclamantes apresentaram pareceres elaborados pelos professores Diego Corapi e Marcelo Fernandez Trindade que concluíram respectivamente:

À luz da legislação italiana, a alienação de ações que atribuem o controle de fato sobre determinada companhia implica em real transferência do poder de controle, ainda que, desobrigue a realização de oferta pública, por ser inferior a $30 \%$. Assim afirma em seu parecer:

\footnotetext{
"de acordo com o ordenamento italiano, a alienação de uma participação à qual corresponda a disponibilidade de votos idôneos para permitir o exercício de uma influência dominante na assembléia ordinária, determina a obrigação por parte do adquirente de promover oferta pública de aquisição da totalidade das ações em circulação, nos termos do artigo 106 do TUF [Texto Único para Finanças Decreto Legislativo $\mathrm{n}^{\circ} 58$ de 24/2/1998], desde que o objeto da aquisição represente participação superior ao patamar de $30 \%$, mas, de qualquer caso, comporta a submissão do adquirente à normativa em matéria de controle de que trata o artigo 2359 do Código Civil Italiano.

Portanto, se Olimpia S.p.a., enquanto titular de ações representativas de 17,99\% do capital de Telecom Itália S.p.a., exercia o controle de fato sobre tal sociedade, então, a alienação de $100 \%$ do capital de Olimpia S.p.a. comportou a transferência de tal controle de fato em favor da adquirente, Telco S.p.a."
} 
Pelo parecer do professor Corabi, o percentual de 30\% que dispara a necessidade de formulação de OPA na Itália serve como uma presunção relativa de controle já que a Diretiva Européia delegou aos Estados membros a determinação dos percentuais de direito de voto necessários para conferir o controle da sociedade, e a Itália manteve o percentual de $30 \%$.

O professor Marcelo Trindade concluiu em seu parecer que: (i) Embora a Olimpia não detenha e não virá a deter participação de controle de Telecom Italia, Olimpia pode exercer uma influência significativa em todos os assuntos a serem decididos pelo voto dos acionistas assim como pode influenciar algumas atitudes da companhia como resultado de sua indicação da maioria dos atuais membros do Conselho de Administração; (ii) a lei italiana deve reger a definição de controle de Telecom Itália, e portanto, a aplicação de tal lei é que deve definir se Olimpia controlava Telecom Italia, e tendo em vista a incontroversa alienação de controle da própria Olímpia, deve incidir a obrigação dos adquirentes do controle de Olimpia de realizar OPA por alienação indireta de controle de TIM Participações, na forma do art. 254-A da Lei das S.A.

As conclusões apresentadas por Trindade consideraram a existência de um exercício de controle acionário indireto e fundamentaram-se no fato de que:

a) o art. 11 da Lei de Introdução ao Código Civil (LICC), e os princípios de direito internacional aplicáveis à espécie no Brasil, determinam que as sociedades sejam regidas pela lei do país de sua constituição, e portanto Olimpia e Telecom Italia regem-se pela lei italiana;

b) as sociedades estrangeiras que funcionam ou têm interesse no Brasil sujeitam-se às leis brasileiras no que se refere às obrigações que aqui 
contratem, ou que decorram das leis brasileiras, na forma do art. $9^{\circ}$ da LICC;

c) o direito à OPA dos acionistas minoritários integra o status socii dos investidores que adquirem ações de companhias abertas brasileiras, não podendo ser afastado nos casos em que incide, segundo a lei brasileira, a obrigação de realizar OPA;

d) na hipótese de, mesmo ocorrendo alienação indireta de controle de companhia aberta, não ser formulada OPA (i) a CVM não autorizará a transferência do controle, nos termos do art. $254-\mathrm{A}, \S 1^{\circ}$, da Lei das S.A., devendo comunicar tal fato aos órgãos reguladores das atividades da companhia aberta; e (ii) diante da decisão da CVM, a assembléia geral poderá deliberar pela suspensão do exercício de voto do acionista controlador (art. 120 Lei das S.A.).

Como forma de comprovar a alegada alienação de controle acionário, os investidores reclamantes comunicaram à CVM a divulgação de vários registros públicos, veiculados por periódicos, que reiteraram o entendimento quanto à existência de controle de fato de Olimpia sobre Telecom Italia, nos termos dos trechos a seguir transcritos:

- "Olímpia controlava Telecom Itália já que nomeava a maioria dos membros do Conselho de Administração" (Financial Times em 4/4/2007);

- "A Pirelli, que detém o controle de Telecom Itália através de uma holding, Olimpia, declarou na semana passada que tem mantido conversas com a Telefônica..." (The New York Times em 30/4/2007);

- "O consórcio que está tomando o controle efetivo da Telecom Italia mantém autoridade nacional nas mãos de instituições..." (Financial Times em 29/4/2007);

- "Olímpia detêm 18\% das ações ordinárias da Telecom Itália, e em função do sistema "voto li lista" italiano, tem sido capaz de controlar 
a Telecom Italia (Relatório elaborado pela Morgan Stanley em 2/4/2007).

A divulgação de tais informações ao mercado e a não obrigatoriedade de realização de OPA pela alienação do controle acionário apresentada pelos reclamantes é reflexo da frágil regulamentação do mercado de capitais e refletem um enfraquecimento daqueles que a lei atribui como "detetives do mercado", uma vez que, ainda que descaracterizada tal alienação, argumento que não parece preponderar, as informações divulgadas ao mercado deveriam trazer maior segurança para os investidores e para a sociedade de modo geral que passa a formar o juízo de valor sobre a companhia fundado em meras opiniões midiáticas.

Em resposta aos argumentos apresentados pelos investidores reclamantes, a companhia TIM Participações S.A. manifestou-se no sentido de que Telecom Italia não estaria subordinada, nos termos da legislação italiana, à direção, coordenação ou controle de qualquer pessoa física ou jurídica, incluindo no rol mencionado a companhia Olimpia.

Além disso, afirmou que o maior acionista individual da companhia seria Olimpia, porém, ainda assim, minoritário. Alega que em assembléia realizada em 16/4/2007, a Olímpia, em razão de o capital participante na mencionada assembléia totalizar pouco mais de $36 \%$ do capital com direito de voto, a Olímpia determinou a eleição de 15 dos 19 conselheiros independentes, sendo 6 conselheiros independentes dos 15 da lista de Olimpia.

Quanto à manifestação por parte da ANATEL que autorizou a existência de alienação indireta de controle acionário informa que tal autorização deve ser analisada com cautela visto existir modelos regulatórios com distintas características, com especificidade quanto a definição e alcance dos termos "controle" e "transferência". 
Em relação à aplicação do art. 120 da Lei das S.A., aduzida no voto do professor Trindade, afirma que o citado artigo estabelece que "a assembléia-geral poderá suspender o exercício dos direitos do acionista que deixar de cumprir obrigação imposta pela lei ou pelo estatuto, cessando a suspensão logo que cumprida a obrigação" "144 À interpretação dada ao referido artigo afirma que por ser tal dispositivo violador de direitos, deve ser interpretado de forma restritiva, e por conseguinte entender que não figura como violador de norma visto que a responsabilidade de realização de OPA recairia sobre a Telco e não sobre a controladora direta de Tim Participações, nem a Telecom Italia invocando os princípios da pessoalidade, proporcionalidade e da razoabilidade.

Por fim, conclui a companhia que em razão da inexistência de normas de conexão no âmbito de direito internacional privado, aplicar-se-ia o art. $9^{\circ}$ e não o art. 11 da LICC, como defendido pelo professor Trindade, já que aquele artigo estabelece que os fatos e atos jurídicos reger-se-ão pela lei do local de sua constituição ou pela escolha das partes, quando admitida. Dessa forma, tendo em vista que a obrigatoriedade de realização de OPA decorre de lei brasileira e italiana, a sua ocorrência deve ser analisada à luz desta legislação tendo em vista que o contrato de compra e venda firmado entre Telco e Olimpia consiste em relação jurídica originária da obrigação legal.

Tal argumento é claramente questionável uma vez que ao investir o seu capital acionário em companhia brasileira há assunção com relação às obrigações que decorrem de tal negócio, ou seja, o acionista de uma sociedade brasileira deve cumprir as obrigações legais e normativas do país a que pertence esta companhia. Dessa forma, percebe-se que uma obrigação de natureza privada, ainda que originária, não possui o condão de alterar a determinação cogente, como a prevista no art. 254-A da Lei das S.A., sob

\footnotetext{
${ }^{144}$ Segundo dados constantes no MEMO/SRE/GER-1/Nº $164 / 2008$ constante no Processo CVM n ${ }^{\circ}$ $\mathrm{RJ} / 2007-14344$.
} 
pena de ferir a ordem publica nacional e sofrer as sanções decorrentes do descumprimento das determinações legais e normativas.

No presente contexto, cabe aqui ainda mencionar os argumentos apresentados por parte da Commissione Nazionale per Le Societá e la Borsa (CONSOB) ao manifestar-se sobre a operação em tela. Inicialmente, esclarece que é admitida a forma de exercício de controle de fato, porém, estabelece alguns requisitos que devem ser verificados, tais como, a necessidade de continuidade e estabilidade do poder de controle; não sendo adequado admitir o concurso das circunstâncias de modo meramente ocasional ou temporário. Ademais, deve ser levada em consideração a prevalência do poder em número significativo de assembléias que tenham como objeto a deliberação de assuntos importantes à condução da vida social da companhia.

Ao aplicar tais requisitos à operação em análise, a CONSOB manifestou-se no sentido de que necessária é a apresentação da ata de assembléia de acionistas de aprovação de demonstrações financeiras do exercício findo em 31.12.2007 para a caracterização da existência de controle de fato.

Com relação ao posicionamento estabelecido pela Superintendência de Registros de Valores Mobiliários (SRE), houve inicialmente concordância com a análise técnica realizada pela Gerência de Registro de Valores Mobiliários (GER-1) que entendeu descabido o pedido feito pelos acionistas reclamantes por entenderem que o controle de fato restava descaracterizado. Este entendimento prevaleceu na $1^{\text {a }}$ reclamação apresentada, sob o registro do Processo CVM nº RJ/2007/14344.

Entretanto, à decisão da SRE foi interposto recurso ao Colegiado da CVM, por parte de Telco, registrado no Processo CVM no RJ/2009/1956, com o intuito de modificar a decisão do SRE que em despacho registrado no dia 19.01.2009 apresentou discordância com o entendimento 
inicialmente apresentado pela área técnica e houve o reconhecimento de existência de efetivo controle de fato da Telecom Italia exercido pela Olimpia e que continuava sendo exercido pela Telco, concluindo, portanto, pela obrigatoriedade de realização de OPA na operação em questão. Os fatos que argumentaram o despacho mencionado fundaram-se no fato de que: (i) apesar do entendimento da CONSOB de que o fato de Olimpia ter contado com 49,94\% dos votos da Assembléia de 16.4.2007 descaracterizaria o seu controle de fato sobre a Telecom Italia, tal entendimento não deve prevalecer uma vez que já era de conhecimento público a alienação de Olimpia para a Telco quando da realização da referida Assembléia - quando só então a participação atingiu percentual inferior e 50\%. Concluiu que é incontestável o controle exercido pela Telco sobre a Telecom Italia, tornando assim desnecessária a verificação do controle pela Telco na Assembléia Geral ocorrida em 2008.

No julgamento do referido recurso, das questões que balizaram o cerne da questão, serão aqui analisadas (i) a lei aplicável para a caracterização de alienação do controle acionário e (ii) existência ou não de obrigatoriedade de realização de OPA para apurar a necessidade de imposição de realização de OPA por parte de Telco. Efetivando assim a CVM as suas atribuições como órgão de fiscalização, controle e regulação do mercado de capitais brasileiro.

\section{1 - LeI APlicável para A definiçÃo de CONTROLE - BRASILEIRA OU ITALIANA - E A APLICABILIDADE DO ART. 254- A DA LEI no 6.404/76 AO CASO}

O recurso interposto por Telco teve como objetivo modificar a decisão do SRE que concluiu pela necessidade de realização de OPA por esta companhia uma vez ter restado comprovada a existência de "controle 
de fato ${ }^{145}$ " sobre Olimpia e a consequente alienação de controle acionário de suas controladas brasileiras, conforme demonstra despacho preferido ao Processo CVM nº RJ/2007-14344.

Ao analisar a origem do direito aplicável para a definição de controle, o Diretor Relator Eliseu Martins inicialmente esclarece que adoção do precedente Arcelor Mittal $^{146}$, apresentado pelos acionistas reclamantes, não é de todo cabível no presente caso para considerar a lei italiana aplicável para determinação do conceito de controle já que, naquele caso, a obrigatoriedade de OPA decorreu de previsão estatutária.

Afirma que o procedimento para realização da OPA, se cabível, deve ser regido pela legislação brasileira sob a égide do disposto no art. 11 da Lei de Introdução ao Código Civil (LICC), que dispõe:

"As organizações destinadas a fins de interesse coletivo, como as sociedades e as fundações, obedecem à lei do Estado em que se constituírem" ${ }^{147}$, não importando onde estiver o controle ou onde tenha ocorrido a sua transferência.(Grifado)

Por isso, deve-se apurar a existência de alienação de controle ${ }^{148}$ sob a égide do art. 254-A da Lei das S.A, realizando sua interpretação à luz do art. 116 da Lei e do $\S 4^{\circ}$ do art. 29 da Instrução CVM n 361/2002.

\footnotetext{
${ }^{145}$ Nesse sentido é válido citar as palavras do Relator ao referir-se a tal modalidade de poder de controle acionário no presente julgado: "A lei, se quisesse se referir apenas ao controle majoritário, poderia tê-lo feito expressamente ou mesmo se referido à 'maioria absoluta' do capital votante da companhia, e não à 'maioria dos votos nas deliberações da assembléia-geral'. Nesse sentido, Fábio Konder Comparato, ao analisar o art. 116, menciona que 'a fórmula legal abrange o chamado controle minoritário, dado que não se exige a detenção da maioria do capital votante".

${ }^{146} \mathrm{Na}$ análise de tal caso, em decisão proferida em 25.9.2006, o Colegiado da CVM entendeu que "o poder de controle da companhia Arcelor Brasil deve ser definido de acordo com a lei brasileira e o poder de controle da Arcelor, de acordo com a Lei de OPA, sendo que a aquisição do controle da Arcelor (de acordo com a Lei de OPA) transfere também o controle da Arcelor Brasil (pela Lei 6.404/76), por força da relação de dominação existente entre elas". Nessa decisão, acrescentou o então Presidente da CVM Marcelo Trindade que "para saber se uma aquisição de ações de emissão de Arcelor é ou não capaz, ou suficiente, para atingir esse efeito de aquisição do seu controle, é preciso recorrer à lei que rege essa companhia, isto é, a lei de Luxemburgo, segundo o art. 11 da LICC." Entretanto, a apesar das colocações aqui mencionadas, o julgado não pode ser usado como precedente à possibilidade de aplicação de lei estrangeira para a definição de controle uma vez que a obrigação de realização de OPA decorreu de previsão do estatuto da companhia, em caso de alienação de controle, e não em decorrência de aplicação do direito estrangeiro.

${ }^{147}$ Vide Decreto - Lei no ${ }^{\circ} 4657 / 42$.

${ }^{148}$ Considerando-se, obviamente, o controle indireto exercido sobre a sociedade brasileira.
} 
Cumpre ressaltar as palavras por ele utilizadas ao proferir o seu voto:

\begin{abstract}
"A meu ver, tais disposições devem ser interpretadas de acordo com as regras e princípios previstos na legislação brasileira. Como a TIM Participações é companhia com sede no Brasil, entendo que a correta aplicação do art. 11 da LICC ao caso implica que a determinação do seu controle indireto deve tomar como base o conceito de controle indireto previsto na legislação brasileira. Esse também é, s.m.j., o único entendimento que permite que o art. 254-A da LSA cumpra efetivamente a finalidade a que se propõe(...)"
\end{abstract}

Segundo seu entendimento constitui ônus injustificável à companhia brasileira e aos minoritários a imposição da análise da legislação de outros países para acompanhamento das transferências de participações de controladores indiretos já que o art. 254-A da Lei das S.A. impõe ao adquirente do controle de companhia aberta brasileira o dever de realização de OPA. Portanto, a ele deve ser atribuída a responsabilidade pela verificação de se a operação acarreta a obrigatoriedade de realização de OPA no Brasil.

A adoção de direito diverso do brasileiro para a arguição de existência ou não de poder de controle e a alienação ou não do controle acionário traria uma enorme insegurança jurídica aos acionistas minoritários e ao mercado como um todo, como reitera o relator em seu voto.

Argumentou que não cabe ao acionista minoritário investigar em qual país se encontra o controle da companhia onde investe ou pretende investir. Seria muito mais lógico que, de forma contrária, fosse imputada a responsabilidade a quem se interessasse pela aquisição, no exterior, do controle de uma companhia, a verificação das possíveis consequências dessa aquisição, mesmo que o conceito de controle fosse diferente em vários países onde essa companhia tivesse controladas. 
Segundo o Diretor Relator, pela disposição legal do $§ 1^{\circ}$ do art. 254A da Lei das S.A. ${ }^{149}$, o legislador não estabeleceu o critério de efetividade ao exercício do poder de controle acionário, concluindo que, poderia existir o poder de controle "em potência" na medida em que os acionistas detivessem valores mobiliários capazes de permitir o exercício efetivo do poder de condução da vida da sociedade, concluindo que o requisito previsto na alínea "b" do art. 116 (uso efetivo do poder de controle) não é exigido para a caracterização do controle para fins de OPA.

No caso, entretanto, afirma que não há sombras de dúvida quanto ao fato que a suposta controladora (Olimpia) era uma acionista atuante já que esta participava de forma efetiva da vida da Telecom Italia, como pode ser confirmado pela sua atuação nos eventos societários, ao eleger a maior parte dos seus administradores, como registram os dados constantes no voto proferido:

i. antes da operação em análise, a Olimpia, com 17,99\% das ações com direito a voto, era a principal acionista da Telecom Italia;

ii. a Olimpia e a Telco (após a incorporação da Olimpia) elegeram, desde pelo menos 2004, até 2009, conforme documentos constantes dos autos, a grande maioria dos conselheiros da Telecom Italia;

iii. a Olimpia, desde 2004 , teve a maioria do capital votante presente nas assembleias da Telecom Italia. Na AGO de 2007, contudo, não obteve a maioria, mas 49,94\% do capital votante presente. Apesar disso, logrou êxito em eleger a maior parte dos conselheiros naquela assembleia;

iv. nas AGOs de 2008 e 2009 situação semelhante à da AGO de 2007 ocorreu, com as ações da Telco provenientes da Olimpia representando 45,56\% e $45,20 \%$, respectivamente, do capital votante presente nessas mesmas assembleias. Registre-se, complementarmente, que a Telco contou com outros lotes de ações (decorrentes de conferência de ações ao seu capital e de aquisições posteriores) que, somados, propiciaram-lhe $62,06 \%$ e $61,57 \%$ do capital votante presente, respectivamente. Novamente em 2008, a Telco elegeu a maior parte dos conselheiros da Telecom Italia;

\footnotetext{
$149 \S 1^{\text {o }}$ do art. 254-A: "Entende-se como alienação de controle a transferência, de forma direta ou indireta, de ações integrantes do bloco de controle, de ações vinculadas a acordos de acionistas e de valores mobiliários conversíveis em ações com direito a voto, cessão de direitos de subscrição de ações e de outros títulos ou direitos relativos a valores mobiliários conversíveis em ações que venham a resultar na alienação de controle acionário da sociedade."(Grifado).
} 
v. a CONSOB não exigiu, até onde seja do nosso conhecimento, a consolidação das demonstrações financeiras da Telecom Italia na Olimpia, na Telco ou em qualquer de seus sócios.

Como confirmam as palavras do Relator é certo que, até a ocorrência da Operação, a Olimpia teve historicamente a maioria dos votos nas deliberações das Assembléias (com exceção da AGO de 2007) e elegeu a maioria dos administradores da companhia. Por isso, afasta a prerrogativa alegada pela defesa de que o exercício dos direitos de sócio não teriam ocorrido de modo permanente.

Neste sentido, a acepção do termo "de modo permanente" refere-se à idéia de continuidade e ininterrupção em oposição ao exercício do controle meramente ocasional, como reitera entendimento do citado doutrinador Fabio Konder Comparato: ""a preponderância permanente nas deliberações opõe-se à meramente eventual,
isto é, a que depende de fato incerto, para existir",

"preponderância permanente nas deliberações sociais não significa, estritamente falando, situação majoritária prolongada no tempo. Pode alguém adquirir o controle de uma companhia para mantê-lo por curto período, apenas. Durante este, há controle, desde que a preponderância nas deliberações sociais dependa unicamente da vontade do titular de direitos de sócio e não de acontecimentos fortuitos"

Além disso, com base no entendimento da CVM, de acordo com seus precedentes $^{150}$, há caracterização de alienação de controle acionário e a decorrente obrigatoriedade de realização de OPA aos acionistas minoritários, uma vez que se cumprem os seguintes requisitos:

\footnotetext{
150 Fundamentam tal entendimento as decisões proferidas nos seguintes julgados: Processo Administrativo CVM n ${ }^{\circ}$ RJ 2006/7658, julgado em 11.04.2007; Processo Administrativo CVM n ${ }^{\circ}$ RJ 2007/7230, julgado em 11.07.2007; Processo Administrativo CVM n RJ 2007/14099, julgado em 29.01.2008; Processo Administrativo CVM no RJ 2008/4156, julgado em 17.06.2008; e Processo Administrativo CVM nº RJ 2009/0471, julgado em 03.03.2009.
} 
"(a) que a titularidade do poder de controle seja conferida a pessoa ou grupo diverso do anterior detentor do controle por meio de uma efetiva transferência de ações; e (b) que a transferência das ações do bloco de controle seja realizada a título oneroso, não sendo, contudo, imprescindível o pagamento de prêmio ou ágio.”

Sob tais premissas, comprova-se a existência de controle exercido por Olimpia sobre a Telecom Italia uma vez que os acionistas alienantes Pirelli e Sintonia - tinham 100\% do capital votante da Olimpia e, portanto, de fato que controlavam diretamente a Olimpia, sendo tal poder transferido para a Telco (terceiro - estranho à sociedade). Além disso, foi comprovado o pagamento de um prêmio de $40 \%$ sobre o valor de mercado das ações na operação em tal transferência de controle acionário, como demonstram os documentos apresentados aos autos do Processo CVM nº RJ/2007-14344.

Além disso, nos termos do voto aqui apresentado, admitiu o Diretor Eliseu a caracterização do controle indireto de Olimpia sobre a Telecom Italia e reconhecimento do direito do acionista minoritário em desvincularse da companhia quando um novo centro de comando emerge, compensando-se assim a quebra de estabilidade do quadro acionário provocada pela modificação do poder de controle da companhia. Registrou em seu voto a necessidade de proteger o acionista minoritário em tal situação aplicando a premissa de que ao ingressar na sociedade este leva em consideração a figura que conduz os negócios da companhia e a afinidade de estabelece com a mesma ${ }^{151}$.

Comprovou o relator que devida é a aplicação do art. 254-A da Lei das S.A ao caso, devendo ser afastado o argumento apresentado pela defesa no sentido de afastar a obrigatoriedade de OPA ao caso. O Diretor Marcos Barbosa Pinto acompanhou o seu voto.

\footnotetext{
${ }^{151}$ Reiteram-se aqui os fundamentos da obrigatoriedade de realização de OPA por alienação de controle acionário. Havendo quebra da affectio societatis e o do intuito personae decorrente da transferência do poder de direção da sociedade, assegura a lei o direito de retirada do acionista minoritário - efetivado por meio da realização da oferta pública de aquisição de ações.
} 
Ao manifestar-se sobre qual o direito aplicável para a definição de controle o Diretor Eli Loria interpretou que a realização de oferta pública seria condição de eficácia para o negócio jurídico de alienação de controle acionário, previsto no art. 254-A da Lei das S.A. Estaria tal obrigação enquadrada no art. $9^{\circ}$ da Lei de Introdução ao Código Civil, segundo o qual, as obrigações serão qualificadas e regidas pela lei do país em que se constituírem. Assim, a satisfação da condição suspensiva e resolutiva prevista no artigo 254-A possuiria caráter obrigacional e teria como partes os minoritários e o adquirente do controle. Afirma que somente admitindo tal interpretação é que seria possível exigir a realização de OPA no caso de alienação do controle acionário.

Ao caracterizar a figura do controlador, suscita os requisitos estabelecidos no art. 116 da Lei das S.A., quais sejam, exercício permanente dos direitos de sócio que lhe assegure a maioria dos votos na assembléia geral, poder de eleição da maioria dos administradores da companhia e uso efetivo do poder de direção das atividades sociais e orientação no funcionamento dos órgãos da sociedade.

Dessa forma, ao combinar a previsão do $\S 4^{\circ}$ do art. 29 da Instrução CVM n $^{\circ} 361 / 2002$, interpreta que se o alienante é aquele acionista titular de mais de 50\% das ações com direito a voto, ainda que não tenha o poder de eleger a maioria dos administradores. Cumprido tal requisito, estaria obrigado a realizar OPA nos termos do art. 254-A. Em sentido oposto, caso não detenha a maioria das ações com direito a voto, ainda que exerça o "controle de fato", não será obrigado a realizar OPA com base no referido artigo. A justificativa para essa leitura se funda no fato de que o acionista minoritário não poderia alienar "aquilo a que não teria direito".

Conclui o Diretor que, com base nos requisitos estabelecidos pelo art. 254-A, o ordenamento não admitiu o controle minoritário para fins da obrigação de realização de OPA aos minoritários já que estaria tal 
modalidade de poder destituída do caráter de permanência pelo fato de Telco não ter a capacidade de eleger a maioria dos membros do conselho de administração da Telecom Itália. Com base nisso, vota pelo deferimento do recurso no sentido de desobrigar a realização de OPA ao caso.

Nos termos do voto proferido pelo Diretor Otávio Yazbek a lei brasileira seria aplicável para a definição de controle. Argumenta que, sob a ótica levantada pelo Diretor Relator, a admissão da aplicação de lei estrangeira negaria a vigência da lei brasileira uma vez que poderia inexistir no outro país norma que defina o poder de controle ou que o defina segundo requisitos contrários ao estabelecido pela legislação societária brasileira. Dessa forma, a aplicação da lei brasileira torna-se "imperativo lógico" à definição de controle acionário.

Ademais, afirma que o art. 254-A da Lei das S.A. possui como embrião o revogado art. 254 que, em consonância ao previsto no Inciso IV da Resolução $\mathrm{n}^{\mathrm{o}} 401$ do Conselho Monetário Nacional, admitia a possibilidade de controle minoritário ou de fato para fins de alienação de controle acionário. Desse modo, afasta a sua adesão ao argumento apresentado pelo Diretor Eli que diz ser inadmissível a alienação do controle de fato.

Entretanto, apesar de admitir a existência de um poder de controle minoritário, de fato, ou seja, ainda que inferior a $50 \%$, afirma que a posição detida por Olímpia nas deliberações sociais da Telecom Italia não se revestia do caráter de estabilidade e permanência, necessários para a caracterização do controle - motivo pelo qual, entende inaplicável ao caso o art. 254-A da Lei das S.A, votando assim pelo provimento do recurso interposto por Telco e pela inexigibilidade de realização de OPA ao caso.

Ao proferir o seu voto a Presidente da CVM, Maria Helena dos Santos Fernandes de Santana, afirmou que embora o Diretor Relator tenha afastado o precedente do caso Arcelor- Mittal à analise da presente decisão , 
este deveria ser utilizado como parâmetro tendo em vista que a aplicação de direito estrangeiro teria sido utilizada como fundamento para a obrigatoriedade de realização de OPA.

Como afirmado pelo Diretor Relator, tal argumento deve ser afastado já que no julgado referido como precedente a obrigação de realização de OPA não decorreu de aplicação de ordenamento jurídico estrangeiro mas sim de clara previsão do Estatuto da Companhia que determinava a ocorrência de oferta pública aos minoritários em caso de alienação de controle acionário.

Segundo o voto da Presidente o art. 11 da Lei de Introdução ao Código Civil deveria ser utilizado para a definição da obrigação prevista no art. 254-A da Lei das S.A. e o art. $9^{\circ}$ deveria fundamentar a análise quanto à existência ou não de controle acionário. Assim, a OPA por alienação indireta do controle acionário de Tim Participações S.A. seria regida pela lei brasileira (art. $9^{\circ}$ LICC) caso, de acordo com a lei italiana, tenha havido alienação de controle acionário (art. 11 LICC).

Segundo Maria Helena tal entendimento estaria consubstanciado ainda na Diretiva Européia que regula as OPA. Ao fazer tal colocação, cita os seguintes trechos da legislação da comunidade européia:

\footnotetext{
"Nos casos referidos nas alíneas b) e c), as questões relacionadas com a contrapartida proposta no caso de uma oferta, e em particular o preço, assim como as questões relacionadas com o processamento da oferta, em especial a informação sobre a decisão do oferente de lançar uma oferta, o conteúdo do documento relativo à oferta e a divulgação da oferta, serão tratadas de acordo com as regras do Estado-Membro da autoridade competente.(...)"

"(...)No que respeita às questões relacionadas com a informação aos trabalhadores da sociedade visada e às questões relacionadas com o direito das sociedades, em particular a percentagem de direitos de voto que confere o controlo e qualquer derrogação à obrigação de lançar uma oferta, assim como as condições em que o órgão de administração da sociedade visada pode empreender qualquer acção susceptível de conduzir ao fracasso da oferta, as regras aplicáveis e a autoridade competente são as do Estado-Membro em que se situa a sede da sociedade visada."
} 
A partir de tais previsões regulamentares, entende que há semelhança com relação à interpretação que realiza nos termos da Lei de Introdução ao Código Civil ao caso, ou seja, "é de acordo com a lei vigente na Itália que se deve avaliar se a participação acionária da Olimpia adquirida pelos investidores Assicurazioni Generali S.p.A., Sintonia S.A., Intesa Sanpaolo S.p.A., Mediobanca S.p.A. e Telefónica S.A.”

Dessa forma, entende não ter havido alienação do controle acionário de Olimpia já que não teria sido caracterizado nem mesmo o controle de fato ao caso. Neste sentido, entende que a caracterização do mesmo demanda análise complexa da situação e requer a utilização de critérios mais objetivos. Assim, utiliza como fundamento à sua decisão os esclarecimentos prestados pela CONSOB e a análise das decisões das assembléias de 2008 e 2009. Segundo seus argumentos, a participação oriunda de Olimpia resultou em 45,56\% e 45,20\% dos votos presentes a tais assembléias e Telco somente teria atingido percentual superior a $50 \%$ se consideradas não só as ações provenientes da Olimpia, mas também aquelas relativas à contribuição realizada ao capital de Telco por outros acionistas.

Sendo assim, vota pelo deferimento do recurso interposto por Telco e pela inexigibilidade de realização de OPA ao caso. Entretanto, a aplicação da legislação italiana não deve prosperar uma vez que significa desrespeito a preceito brasileiro de ordem pública já que foi caracterizada a alienação do controle acionário indireto da companhia TIM Participações S.A.

Como resultado do presente julgamento, nos termos dos votos apresentados, o Colegiado, por maioria, vencidos os votos do Diretor Relator e do Diretor Marcos Pinto, foi determinada a inexigibilidade de realização de OPA ao presente caso.

Aqui, comprova-se que os acionistas minoritários, apesar da igualdade formal em relação aos controladores, têm sua proteção prejudicada em razão da inexistência de um ordenamento jurídico que 
confira de forma clara o conceito de poder de controle acionário e o direito aplicável em relação à alienação de controle indireto envolvendo companhia estrangeira.

Permite-se assim que a tutela dos minoritários se faça segundo interpretações arbitrárias e sem balizamento em relação ao poder discricionário conferido legalmente ao poder público. 


\section{4 - CONCLUSÃo}

Não se deve olvidar a magnitude que o poder de controle e a propagação de seus efeitos produzem sobre a realidade jurídica, econômica e política no contexto da alienação de controle acionário.

A complexa caracterização e as diversas modalidades de exercício do poder de controle acionário resultam numa dificuldade clara de proteção aos acionistas minoritários quando da modificação do poder diretivo das companhias.

Em tal cenário, a atuação da Comissão de Valores Mobiliários tornase fundamental, já que ao fiscalizar o cumprimento da lei e coibir a prática de ilícitos nas companhias assegura um equilíbrio razoável dentro do quadro acionário, atenua as tensões e evita abusos, enfim, protege as minorias e o seu "status" de acionista. Especificamente em relação ao mecanismo de tag along garantirá a participação dos minoritários no ágio eventualmente pago pelo controle e o direito de saída da companhia, nos termos do art. 254-A da Lei das S.A.

Entretanto, neste sentido, nota-se que a legislação societária brasileira permite um exercício discricionário ilimitado ao Estado julgador, possibilitando o cometimento de claras injustiças em alguns julgados do Colegiado da CVM. Ainda que com cunho prático, assemelhando-se àquela que foi marcada pela retirada da Emenda Lehmann - responsável por condicionar a alienação de controle das companhias abertas à realização de OPA aos minoritários - nos termos do revogado art. 254 da Lei das S.A. Como demonstram as palavras de Lehmann ao falar sobre o assunto em entrevista realizada pela Revista Capital Aberto ${ }^{152}$ :

"_O que levou o senhor a propor a famosa Emenda Lehmann no Senado: $\mathrm{Na}$ época, eu era advogado militante e vários clientes me contavam a situação

${ }^{152}$ In: Direitos Iguais Revista Capital Aberto publicada em Julho de 2006 - página 30 - 31. 
lamentável que se repetia quando uma empresa era vendida. Os acionistas minoritários não ganhavam nada e tinham que se acertar com o novo dono. Isso me chocou muito."

Assim, apesar dos avanços legislativos quanto à proteção das minorias por meio da obrigatoriedade de realização de OPA em decorrência da alienação de controle acionário, trazida ao nosso ordenamento segundo proposta do ilustre Otto Cyrillo Lehmann, carecemos de efetivação de limitadores com relação ao direito aplicável em situações que envolvem companhia estrangeira detentora de controle acionário brasileiro. Não se deve permitir interpretação da lei que nela encontre o que lá não está, restringindo ainda mais o direito dos minoritários.

Caso contrário, o mercado de capitais estará fadado a um retrocesso com relação aos direitos societários assegurados até então já que a confiança e segurança jurídica das relações societárias restarão afastadas.

Especificamente em relação ao caso analisado, não restou dúvida com relação à possibilidade de consideração do exercício do poder de controle de fato, apesar de não ter previsão expressa legalmente. Entretanto, a inexistência de regras que definam de forma expressa a legislação aplicável em caso de alienação de controle acionário indireto, tornou controversa a questão e tornou inaplicável o art. 254-A ao caso.

Pela exposição realizada no presente trabalho verificou-se que a oferta pública de aquisição de ações obrigatória está inserida em um processo de evolução regulamentar no qual o legislador tem estabelecido limites e responsabilidades com relação aos poderes daqueles que exercem o poder de diretivo da sociedade. Assim, a obrigação prevista no art. 254-A, apesar da problemática em sua aplicação, constitui avanço na conquista dos direitos societários e na garantia de segurança jurídica e defesa do mercado de capitais como em todo. 


\section{REFERÊNCIAS BIBLIOGRÁFICAS}

ABRÃO, Carlos Henrique. Direito das Minorias. In: Lobo, Jorge (Coord.). Reforma da Lei das Sociedades Anônimas.São Paulo: Forense, 2002. p. 249 -284 .

ALMEIDA, José Gabriel Assis de. O Direito das Minorias: a Reforma da Lei de Sociedades por ações e o Anteprojeto de Lei sobre Sociedades de Responsabilidade Limitada. In: Lobo, Jorge (Coord.).Reforma da Lei das Sociedades Anônimas.São Paulo: Forense, 2002. p. 307 - 320.

ANDREZO, Andrea Fernandes. A alienação de controle de companhia aberta e a recente reforma da legislação societária - Efetivo Avanço? In: Revista de Direito Mercantil, Industrial, Econômico e Financeiro. São Paulo: Malheiros, n.130 - abril - junho 2003.p.161-179

BERLE JR., Adolph A. MEANS, Gardiner C. The modern corporation and private property. $1^{\mathrm{a}} \mathrm{ed}$. Buffalo: William S. Hein, 2000.p.244.

BORBA, José Edwaldo Tavares. Direito Societário.11ª Ed.Rio de Janeiro: Renovar, 2008. 572p.

BULGARELli, Waldirio. Regime Jurídico da Proteção às Minorias nas S/A. (De acordo com a reforma da Lei $\mathrm{n}^{\mathrm{o}}$ 6.404/76). Rio de Janeiro: Renovar. 1998. 416p.

CANTIDIANO, Luiz Leonardo. Características das Ações, Cancelamento de Registro e "Tag Along" In: Lobo, Jorge (Coord.). Reforma da Lei das Sociedades Anônimas. 2a ed. São Paulo: Forense, 2002. p. 61 -105.

CARNELUTTI, Francesco. Teoria geral do direito. São Paulo: Lejus.1999. p. 38 . 
CARVALHOSA, Modesto. Comentários à Lei de Sociedades Anônimas. 2.ed. São Paulo: Saraiva, 2003.p.429.

CARVAlHOSA, Modesto. Oferta Pública de Aquisição de Ações. Rio de Janeiro: IBMEC- Instituto Brasileiro de Mercado de Capitais, 1979.211p.

CLEMENTE Júnior, José Alberto. Oferta Pública de Aquisição de Ações na Alienação de Controle de Companhias Abertas - Apontamentos sobre o art. 254 -A da Lei das Sociedades Anônimas: In Revista de Direito Mercantil, Industrial, Econômico e Financeiro.São Paulo: Malheiros.janmarço 2003.Vol. 129.p. 206 - 219.

COELHO, Fabio Ulhoa. O Direito de Saída Conjunta ("Tag Along”) In: Lobo, Jorge (Coord.). Reforma da Lei das Sociedades Anônimas.São Paulo: Forense, 2002. p. 473 - 486.

COMPARATO, Fábio Konder; FILHO, Calixto Salomão.O poder de Controle Acionário. $4^{\mathrm{a}}$ Ed. Rio de Janeiro: Forense,2005.507p.

EIZIRICK, Nelson; GAAL, Ariádna B.; PARENTE, Flávia; HENRIQUES, Marcus de Freitas. Mercado de Capitais Regime Jurídico. $2^{\mathrm{a}}$ Ed.Rio de Janeiro: Renovar,2008.636p.

FERNANDES, Flavia Mouta. El caso de la OPA de Arcelor Brasil S.A. Revista Iberoamericana de Mercados de Valores, Revista Cuatrimestral, Madrid: Julio 2008 n 24. p. 11-17.

FILHO, Alfredo Lamy; PEDREIRA, José Luiz Bulhões. A Lei das S.A.Rio de Janeiro: Renovar,1992.885p.

FILHO, Alfredo Lamy; PEDREIRA, José Luiz Bulhões. Direito das Companhias. $1^{a}$ ed. Vols. 1 e 2. Rio de Janeiro: Editora Forense, 2009. $2175 p$. 
GREGÓRIO, Danilo; AZEVEDO, Simone. In: Revista Capital Aberto publicada em Setembro de 2009. De Direito e de Fato. - p.68.

LOBO, Jorge. Interpretação Realista da Alienação de Controle de Companhia Aberta. In: Lobo, Jorge (Coord.). Reforma da Lei das Sociedades Anônimas.São Paulo: Forense, 2002. p. 505 -524.

OLIVEIRA, Fernando Albino de. A alienação do controle societário na Lei das S.A. In: JAIRO SADDI (org.). Fusões e Aquisições: aspectos jurídicos e econômicos. São Paulo: IOB.2002.p. 227-228.

PARENTE, Norma. Principais inovações introduzidas pela Lei n. 10.303, de 31 de Outubro de 2001, à Lei de Sociedades por ações. In: Lobo, Jorge (Coord.).Reforma da Lei das Sociedades Anônimas.São Paulo: Forense, 2002. p. $11-49$.

PRADO, Roberta Nioac. Oferta Pública de Ações Obrigatória nas S.A. Tag Along. $1^{\circ}$ ed. São Paulo: Quartier Latin, 2005. 366p.

Revista Capital Aberto publicada em Julho de 2006. Direitos Iguais Edição Especial. p. $30-33$.

SANTOS, J. A. Penalva. Direito dos minoritários - Alienação de Controle de Companhia Aberta e os Direitos dos Minoritários.Análise do art. 254 da Lei $n^{o}$ 6.404 de 1976.In: Lobo, Jorge (Coord.).Reforma da Lei das Sociedades Anônimas.São Paulo: Forense, 2002. p. 487 -503.

SIQUEIRA, Carlos Augusto Junqueira de. Transferência do controle acionário: interpretação e valor. Rio de Janeiro: FMF Ed., 2004.520p.

WALD, Arnoldo. A Reforma da Lei das Sociedades Anônimas: os Direitos dos Minoritários na Nova Lei das S.A. In: Lobo, Jorge (Coord.). Reforma da Lei das Sociedades Anônimas.São Paulo: Forense, 2002. p. 219 -247 
Relatório da Reunião Extraordinária do Colegiado da CVM de 15.07.2009, Reg. $n^{o}$ 6360/08 relativa ao Processo CVM $n^{o}$ RJ-2009/1956. Disponível em <www.cvm.gov.br >. Acesso em 11 out. 2010.

Regulamento do Novo Mercado. Disponível em 〈http://www.bmfbovespa.com.br/Pdf/RegulamentoNMercado.pdf >; Acesso em 11 out. 2010.

Julgados Administrativos citados no Âmbito da Comissão de Valores Mobiliários - CVM. Disponível em <www.cvm.gov.br>. Acesso em 11 out. 2010.

MEMO/SRE/GER-1/N $164 / 2008$ constante no Processo CVM n ${ }^{\circ} \mathrm{RJ} / 2007$ 14344 